\title{
Glucagon like peptide-1 receptor agonist (GLP-1RA) therapy in management of type 2 diabetes: choosing the right agent for individualised care
}

\author{
ZIN ZIN HTIKE, 1,2 FRANCESCO ZACCARDI, 1,2 SUDESNA CHATTERJEE, 1,2 KAMLESH KHUNTI, 1,2 \\ MELANIE J DAVIES 1,2
}

\begin{abstract}
Glucagon like peptide-1 receptor agonists (GLP-1RAs) are a new class of injectable agent used in the management of type 2 diabetes (T2DM). In the UK, NICE approved the use of GLP-1RAs in combination with metformin and sulphonylurea in people with T2DM whose glycaemic control is above target $(\geq 7.5 \%, 58 \mathrm{mmol} / \mathrm{mol})$ and body mass index (BMI) $\geq 35 \mathrm{~kg} / \mathrm{m}^{2}$ with other medical problems associated with obesity or for whom insulin therapy would have significant occupational implications or weight loss would benefit other significant obesityrelated comorbidities in people with BMI $<35 \mathrm{~kg} / \mathrm{m}^{2}$. Unlike many other classes of glucose lowering agents, GLP-1RAs not only improve glycaemic control but also promote weight loss with a low risk of hypoglycaemia. In randomised controlled trials, treatment with GLP-1RAs either as monotherapy or in combination with oral hypoglycaemic agents or insulin, has demonstrated significant improvement in glycaemic control by $1-2 \%$ with weight loss of approximately $1-5 \mathrm{~kg}$. In addition, they exert a positive effect on cardio-metabolic risk factors by reducing body weight, lowering blood pressure and improving the lipid profile. Gastrointestinal side effects are the most common adverse events with GLP-1RA therapy. Since the first GLP-1RA was approved in 2005, a number of other GLP-1RAs are now available. However, their glycaemic efficacy, safety profiles and mode of delivery differ, and this review article aims to give an overview of differences among GLP-1RAs and to provide decision makers with an overview of the evidence when choosing a particular GLP1RA for individualised therapy.

Br J Diabetes 2016;16:128-137
\end{abstract}

Diabetes Research Centre, University of Leicester, Leicester, UK Leicester Diabetes Centre, Leicester General Hospital, University Hospitals of Leicester NHS Trust, UK

Address for correspondence: Dr Zin Zin Htike

Leicester Diabetes Centre, Leicester General Hospital, Leicester, UK.

Tel: +44 (0)116258 8602

E-mail: zzhtike@gmail.com

http://dx.doi.org/10.15277/bjd.2016.091
Key words: diabetes, GLP-1 receptor agonist, glycaemic control, cardiovascular risk factor, efficacy, safety

\section{Introduction}

Type 2 diabetes (T2DM) is a metabolic disorder characterised by chronic hyperglycaemia due to complex pathophysiological mechanisms recently described as the "ominous octet". 1 This includes reduced insulin secretion from $\beta$-cells, increased glucagon production from $\alpha$-cells, increased hepatic glucose output, increased lipolysis, increased renal glucose reabsorption, insulin resistance (in the periphery, where it reduces glucose uptake, and in the brain, where it promotes greater food intake), neurotransmitter dysfunction, and a reduced incretin effect. 1,2 Incretins are gut hormones produced from intestinal cells in response to oral glucose ingestion, which in turn stimulates insulin secretion. In people without diabetes, an oral glucose load elicits a greater insulin response than intravenous glucose administration, known as the "incretin effect". ${ }^{3}$ However, this effect is blunted in people with T2DM. ${ }^{4}$ With a better understanding of the incretin effect in people with T2DM and specifically targeting the incretin system, a novel class of therapeutic agents, called glucagon like peptide-1 receptor agonists (GLP-1RAs) has been developed. In addition to glucose-dependent insulin secretion, GLP-1RAs suppress glucagon production, reduce hepatic glucose output, inhibit satiety centre and delay gastric emptying, resulting in improved glucose control and promoting weight loss. ${ }^{5}$

The first GLP-1RA, exenatide, was approved by the US Food and Drug Administration (FDA) in 2005. Although structured education and life-style modifications are the basic pillars in managing T2DM, achieving and maintaining glycaemic control becomes a challenge as the condition progresses despite the availability and use of multiple glucose lowering therapies. ${ }^{2}$ Moreover, the conventional therapies used in the management of T2DM can be associated with undesirable side effects such as hypoglycaemia and weight gain. However, treatment with GLP1 RAs has the added benefit of weight loss and a low risk of hypoglycaemia in addition to improving glycaemic control. They have been shown to improve cardiovascular risk factors in many studies.

All GLP-1RAs available to date are administered subcutaneously either daily or once weekly. Exenatide (Byetta ${ }^{\circledR}$ ), liraglu- 
tide $\left(\right.$ Victoza $\left.^{\circledR}\right)$ and lixisenatide (Lyxumia $\left.{ }^{\circledR}\right)$ are daily preparations whereas once-weekly exenatide (Bydureon $\left.{ }^{\circledR}\right)$, albiglutide (Eperzan ${ }^{\circledR}$ or Tanzeum ${ }^{\circledR}$ ), dulaglutide (Trulicity ${ }^{\circledR}$ ), semaglutide (in development) and taspoglutide (discontinued) are once-weekly preparations. In order to retain the mode of action for an extended period, they have been formulated either as microspheres (once-weekly exenatide), combined with recombinant human albumin (albiglutide), bound to modified human IgG4 (dulaglutide), increased albumin affinity and secured full stability against metabolic degradation (semaglutide) or modified amino acid sequence (taspoglutide). To date, once-weekly, exenatide $(2 \mathrm{mg}$ ), albiglutide (30 or $50 \mathrm{mg}$ ) and dulaglutide $(0.75$ or $1.5 \mathrm{mg}$ ) are licensed by the FDA and European Medicine Agency (EMA) to be used in the management of T2DM. Development of taspo-glutide (10 or $20 \mathrm{mg}$ ) was discontinued in 2010 due to undue side-effects and therefore it is not clinically available while semaglutide is being studied in phase 3 trials. ${ }^{6}$

The American Diabetes Association (ADA)/European Association for the Study of Diabetes (EASD) guidelines recommend the use of GLP-1RAs as an adjunctive therapy to life style modification and metformin. ${ }^{7}$ In the UK, the use of GLP-1RAs is advocated by the National Institute for Health and Care Excellence (NICE) in patients with T2DM who have a body mass index (BMI) $\geq 35 \mathrm{~kg} / \mathrm{m}^{2}$ and $\mathrm{HbA}_{1 \mathrm{c}} \geq 7.5 \%$ (58 mmol/mol) unless comorbidities such as obstructive apnoea or occupational issues precluding insulin use are present. This article aims to review the clinically relevant cardio-metabolic efficacy and safety of currently licensed GLP-1RAs including twice-daily $(10 \mu \mathrm{g})$ exenatide (EBID), ${ }^{8-19}$ liraglutide (1.2 or $1.8 \mathrm{mg}$, LEAD studies), ${ }^{20-26}$ once-weekly exenatide ( $2 \mathrm{mg}$, DURATION studies), ${ }^{27-32}$ lixisenatide $(20 \mu \mathrm{g}$, GetGoal studies), 33-42 albiglutide (30 mg, HARMONY studies)43-49 and dulaglutide (1.5 mg, AWARD studies) (Tables 1-2). ${ }^{50-55}$

\section{Efficacy of GLP-1RAs on cardio-metabolic parameters Effect on glycaemic control and body weight}

The glycaemic efficacy and changes in body weight are summarised in Supplementary Tables S1-6 (see Appendix 1, available online at bjd-abcd.com). Therapy with GLP-1RAs, either as monotherapy or in combination with oral hypoglycaemic agents including metformin, sulphonylurea (SU) or thiazolidinediones (TZD), has demonstrated improvement in glycaemic control. Compared to placebo, significant $\mathrm{HbA}_{1 \mathrm{c}}$ reductions were observed with both daily and once-weekly GLP-1RAs; $0.5-1.0 \%$ with EBID, $0.6-1.1 \%$ with liraglutide, $0.3-1.1 \%$ with lixisenatide, $0.8-1.0 \%$ with albiglutide, $1.0-1.2 \%$ with dulaglutide (Tables S1-6). Marginally greater difference was noted when compared to metformin. 30,52 However, GLP1 RAs have shown significantly better glycaemic control compared with SU and TZD. HbA 1 c reductions were $0.4-0.6 \%$ with liraglutide (vs SU), ${ }^{21,22} 0.6-0.7 \%$ with liraglutide (vs TZD), ${ }^{20}$ and $0.3 \%$ with once-weekly exenatide (vs TZD), ${ }^{28}$ respectively. Likewise, a significantly greater reduction in $\mathrm{HbA}_{1 c}$ of $0.4-0.6 \%$ was observed with liraglutide, once-weekly exenatide and albiglutide compared with sitagliptin. ${ }^{26,28,49}$ Short acting GLP-1RAs (EBID) are equivalent in glycaemic efficacy to basal insulin whereas long acting GLP-1RAs (once-weekly exenatide, liraglutide, albiglutide and dulaglutide) are superior to basal insulin by $0.2-0.6 \% .14,15,17,19,24,29,46,48,51,53$ Addition of GLP-1RAs exenatide and lixisenatide to insulin resulted in further $\mathrm{HbA}_{1 \mathrm{c}}$ reduction of $0.5-0.7 \%$ in both randomised controlled trials (RCTs) and observational studies. ${ }^{18,34,41,42,56,57}$

In head to head comparisons (Table 1), once-weekly exenatide, dulaglutide and liraglutide $1.8 \mathrm{mg}$ were associated with better glycaemic control compared to EBID; $\mathrm{HbA}_{1 c}$ reductions were $0.5-0.7 \%(p<0.0001), 27,310.7 \%(p<0.001)^{50}$ and $0.3 \%$ $(p<0.0001)$ respectively. ${ }^{25}$ Compared with liraglutide $1.8 \mathrm{mg}$, dulaglutide and once-weekly exenatide showed marginally better $\mathrm{HbA}_{1 c}$ reductions of $0.1 \%(p<0.0001)^{55}$ and $0.2 \%$ $(p=0.02),{ }^{32}$ suggesting that these GLP-1RAs may have similar glycaemic efficacy clinically. Among daily GLP-1RAs, liraglutide was more efficacious in achieving glycaemic control than lixisenatide and EBID by $0.6 \%$ and $0.3 \%$ respectively $(p<0.0001) .25,58$ However, no significant difference was found between lixisenatide and EBID. ${ }^{36}$

GLP-1RAs also improved fasting plasma glucose (FPG) compared with placebo in a similar pattern to $\mathrm{HbA}_{1 \mathrm{c}}$ reductions, ranging from $0.7-2.8 \mathrm{mmol} / \mathrm{L}$, contributing to overall improvements in glycaemic control (Tables S1-6). However, basal insulin glargine was superior to GLP-1RAs, EBID, once-weekly exenatide, albiglutide and dulaglutide. 14,16,17,46,53 GLP-1RAs also attenuate postprandial glucose (PPG) excursion and reductions were greater with daily GLP-1RAs, EBID, 59 liraglutide (LEAD 1-5) 60 and lixisenatide (GetGoal studies). ${ }^{33-42}$ Compared with a longer acting liraglutide, EBID and lixisenatide (short acting GLP1 RAs) yielded greater PPG reduction with a treatment difference of $1.4-2.5 \mathrm{mmol} / \mathrm{L}(p<0.001){ }^{25,58,61}$

In RCTs, treatment with GLP-1RAs has consistently shown a beneficial effect on weight loss. Compared with placebo, weight reductions were -1.6 to $-2.8 \mathrm{~kg}$ with EBID, -1.4 to $-2.6 \mathrm{~kg}$ with liraglutide, -0.5 to $-1.3 \mathrm{~kg}$ with lixisenatide, and -2.5 to $-3.5 \mathrm{~kg}$ with exenatide once-weekly and dulaglutide. This is in line with the findings in a mixed treatment analysis. ${ }^{62}$ However, no significant change in weight was observed with albiglutide compared to placebo in HARMONY studies. ${ }^{47,63}$ Unlike weight gain with other conventional therapies such as SU, TZD or insulin, treatment with both daily and once-weekly GLP-1RAs resulted in significant weight loss; $-2.8 \mathrm{~kg}(p<0.0001),-5.1 \mathrm{~kg}(p<0.0001)$,

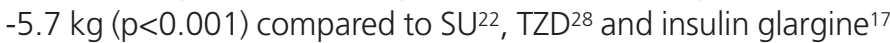
respectively. Weight loss was also significantly greater with GLP1RAs (1.9-2.3 kg, p<0.001) when compared to the weight neutral agent sitagliptin. $26,28,30 \mathrm{In}$ a head to head comparison of GLP-1RAs, the greatest difference in weight was observed with liraglutide $1.8 \mathrm{mg}$ vs albiglutide $(-1.5 \mathrm{~kg}, \mathrm{p}<0.0001) .49$

In addition, a dose related weight loss effect was observed with liraglutide $1.2 \mathrm{mg}$ and $1.8 \mathrm{mg}$ in the LEAD studies. ${ }^{60} \mathrm{In}$ the recently published SCALE Diabetes study, a higher dose of liraglutide (3 mg) promoted greater weight loss with $6 \%$ reduction of initial body weight when compared to lower doses, $4.7 \%$ $\left(1.8 \mathrm{mg}\right.$ ) and $2 \%$ (placebo) in people with diabetes. ${ }^{64}$ Similarly, weight loss was maintained at 56 weeks with liraglutide $3 \mathrm{mg}$ in people without diabetes when compared to placebo $(-8.0 \%$ vs $-2.6 \%,<0.001) .65$ 
Table 1 Summary of randomised controlled trials comparing one GLP-1RA against another

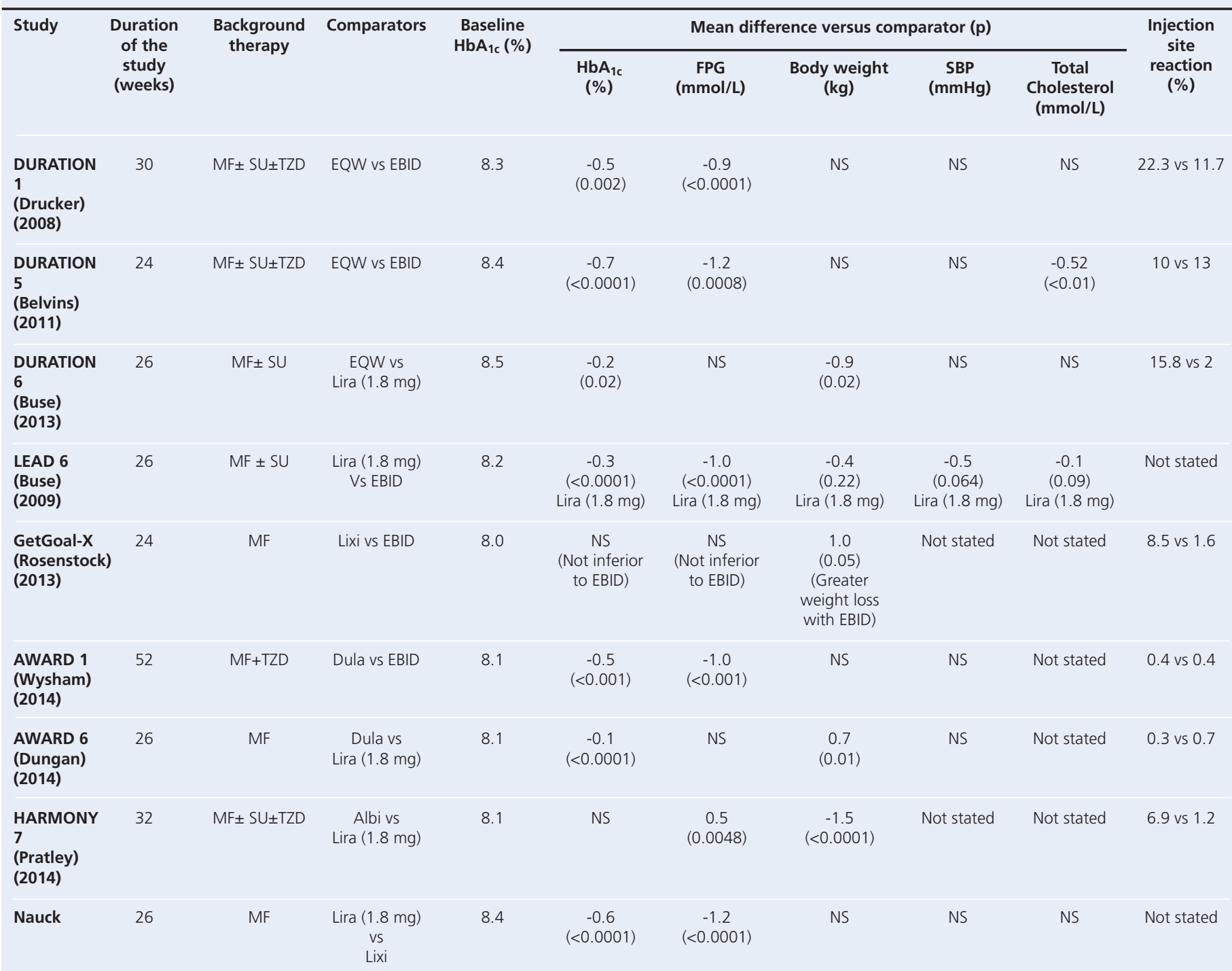

MF=Metformin, SU=Sulphonylurea, TZD=Thiazolidinediones, EBID= Twice-daily exenatide (10 mcg BD), EQW=Once-weekly exenatide , Lira=Liraglutide, Lixi=Lixisenatide, Albi=Albiglutide $(30 \mathrm{mg})$, Dula=Dulaglutide $(1.5 \mathrm{mg})$, NS=Not significant

\section{Effect on cardiovascular risk factors}

Treatment with GLP-1RAs is associated with a modest reduction in systolic blood pressure (SBP), -2.2 to $-7.5 \mathrm{mmHg}$ with EBID (Table S1),-0.9 to $-5.6 \mathrm{mmHg}$ with liraglutide (Table S2) and -2.0 to $-4.0 \mathrm{mmHg}$ with once-weekly exenatide (Table S4). In a meta-analysis, once-daily GLP-1RAs (exenatide and liraglutide) decreased SBP by $-1.8 \mathrm{mmHg}$ and $-2.4 \mathrm{~mm} \mathrm{Hg}(p<0.001)$ compared to placebo and active control, respectively. However, reduction in diastolic blood pressure failed to reach statistical significance; $-0.5 \mathrm{mmHg}$ vs placebo and $-0.5 \mathrm{~mm} \mathrm{Hg}$ vs active control. 66 In addition, a meta-analysis of 35 RCTs showed that GLP-1RAs were associated with modest reductions in total cholesterol, LDL-C, and triglycerides but no significant improvement in HDL-C. ${ }^{67}$ Exenatide and liraglutide $1.8 \mathrm{mg}$ decreased total cholesterol by -0.16 to $-0.27 \mathrm{mmol} / \mathrm{L}(\mathrm{p}<0.001)$ versus placebo and TZD. The decrease was more evident with once-weekly exenatide and liraglutide $1.8 \mathrm{mg}$ once daily. A significant reduction in LDL-C was detected for all GLP-1RAs versus placebo, insulin and TZD. A significant reduction in triglyceride levels was observed with liraglutide $1.8 \mathrm{mg}(-0.30 \mathrm{mmol} / \mathrm{L}, \mathrm{p}<0.0001)$ versus placebo. ${ }^{67}$

Although GLP-1RAs showed improvements in SBP and lipid profile, there was an increase in heart rate of 0.9, 2.1, 2.7 and $2.2 \mathrm{bpm}$ with EBID, once-weekly exenatide, liraglutide and dulaglutide, respectively, when compared with placebo. ${ }^{66}$ In head to head comparisons, longer acting GLP-1RAs raised the pulse rate significantly more than short acting ones; $3.6 \mathrm{bpm}(\mathrm{p}=0.0001)^{58}$ with liraglutide vs lixisenatide and $1.6 \mathrm{bpm}(\mathrm{p}<0.05)$ with dulaglutide vs EBID (AWARD 1). No significant difference in heart rate was noted between liraglutide and dulaglutide (AWARD 6) or between lixisenatide and EBID (GetGoal-X). The impact of increased heart rate remains unclear. Further evidence is needed to determine if 
Table 2 Factors to consider in clinical use comparing one GLP-1RA against another

\begin{tabular}{|c|c|c|c|c|c|c|c|c|}
\hline $\begin{array}{l}\text { GLP-1RA } \\
\text { (Approved } \\
\text { by } \\
\text { FDA/EMA) }\end{array}$ & $\begin{array}{c}\text { Class } \\
\text { Long acting (L) } \\
\text { or } \\
\text { Short acting(S) }\end{array}$ & $\begin{array}{c}\text { Dose titration } \\
\text { and frequency } \\
\text { used in } \\
\text { clinical practice }\end{array}$ & $\begin{array}{c}\mathrm{HbA}_{1 c} \\
\text { reduction } \\
(\%)\end{array}$ & $\begin{array}{c}\text { Pronounced } \\
\text { effect } \\
\text { on FPG } \\
\text { or PPG }\end{array}$ & $\begin{array}{l}\text { Weight loss } \\
\text { (kg) }\end{array}$ & $\begin{array}{l}\text { Licensed to } \\
\text { be used } \\
\text { with } \\
\text { insulin UK }\end{array}$ & $\begin{array}{c}\text { eGFR } \\
\left(\mathrm{ml} / \mathrm{min} / 1.73 \mathrm{~m}^{2}\right)\end{array}$ & $\begin{array}{c}\text { CV } \\
\text { Outcomes } \\
\text { study }\end{array}$ \\
\hline $\begin{array}{l}\text { Twice-daily } \\
\text { Exenatide } \\
\left.\text { (Byetta }{ }^{\circledR}\right) \\
\text { (FDA/EMA) }\end{array}$ & $S$ & $\begin{array}{c}5 \mu \mathrm{g} \mathrm{BD} \\
(4 \text { weeks) } \\
10 \mu \mathrm{g} \mathrm{BD} \\
\text { (maintenance dose) } \\
\text { Within } 60 \text { min } \\
\text { of meal }\end{array}$ & $0.5-1.0$ & PPG & $1.5-2.0$ & Basal insulin & $\begin{array}{c}\text { No dose } \\
\text { adjustment } \\
\text { if } 50-80 \\
\text { Cautious } \\
\text { escalation of } \\
\text { dose if } 30-50 \\
\text { Avoid if }<30\end{array}$ & \\
\hline $\begin{array}{l}\text { Lixisenatide } \\
\left.\text { (Lyxumia }^{\circledR}\right) \\
\text { (FDA/EMA) }\end{array}$ & $\mathrm{S}$ & $\begin{array}{c}10 \mu \mathrm{g} \mathrm{OD} \\
\text { (14 days) } \\
20 \mu \mathrm{g} \text { OD } \\
\text { (maintenance } \\
\text { dose) } \\
\text { Within the hour } \\
\text { prior to the first } \\
\text { meal of the day or } \\
\text { the evening meal }\end{array}$ & $0.5-1.0$ & PPG & $1.0-1.5$ & Basal insulin & $\begin{array}{c}\text { No dose } \\
\text { adjustment } \\
\text { if 50-80 } \\
\text { Cautious } \\
\text { escalation of } \\
\text { dose if } 30-50 \\
\text { Avoid if }<30\end{array}$ & ELIXA \\
\hline $\begin{array}{l}\text { Liraglutide } \\
\left.\text { (Victoza }^{\circledR}\right) \\
\text { (FDA/EMA) }\end{array}$ & $\mathrm{L}$ & $\begin{array}{c}0.6 \mathrm{mg} \text { OD } \\
\text { (1 week) } \\
1.2 \mathrm{mg} \text { OD } \\
\text { (maintenance dose) } \\
1.8 \mathrm{mg} \text { OD } \\
\text { (exceptional } \\
\text { circumstance) } \\
\text { Anytime of the } \\
\text { day with or } \\
\text { without meal }\end{array}$ & $1-1.5$ & FPG & $1.0-3.5$ & Basal insulin & $\begin{array}{l}\text { No dose } \\
\text { adjustment if } \\
30-90 \\
\text { Avoid if <30 }\end{array}$ & LEADER \\
\hline $\begin{array}{l}\text { Once-weekly } \\
\text { Exenatide } \\
\text { (Bydureon }{ }^{\circledR} \text { ) } \\
\text { (FDA/EMA) }\end{array}$ & $L$ & $\begin{array}{l}2 \text { mg once weekly } \\
\text { Anytime of the } \\
\text { day with or } \\
\text { without meal }\end{array}$ & $1.5-2.0$ & FPG & $1.5-3.0$ & Not licensed & $\begin{array}{l}\text { No dose } \\
\text { adjustment } \\
\text { if 50-90 } \\
\text { Avoid if <50 }\end{array}$ & EXSCEL \\
\hline $\begin{array}{l}\text { Dulaglutide } \\
\left(\text { Trulicity }^{\circledR}\right) \\
\text { (FDAVEMA) }\end{array}$ & $\mathrm{L}$ & $\begin{array}{c}1.5 \text { mg once weekly } \\
\text { Anytime of } \\
\text { the day with or } \\
\text { without meal }\end{array}$ & $1.0-2.0$ & FPG & $1.5-3.0$ & Insulin & $\begin{array}{l}\text { No dose } \\
\text { adjustment } \\
\text { if 50-90 } \\
\text { Avoid if <30 }\end{array}$ & REWIND \\
\hline $\begin{array}{l}\text { Albiglutide } \\
\text { (Tanzeum }^{\circledR} / \\
\text { Eperzan }^{\circledR} \text { ) } \\
\text { (FDA/EMA) }\end{array}$ & $L$ & $\begin{array}{l}\text { 30-50 mg } \\
\text { once weekly } \\
\text { Anytime of } \\
\text { the day with or } \\
\text { without meal }\end{array}$ & $0.4-0.8$ & FPG & $0.2-1.2$ & Basal insulin & $\begin{array}{l}\text { No dose } \\
\text { adjustment } \\
\text { if 30-90 } \\
\text { Avoid if <30 }\end{array}$ & \\
\hline
\end{tabular}

improvements in SBP and lipid profiles might translate into reductions in cardiovascular outcomes.

\section{Safety and tolerability of GLP-1RAs}

\section{Gastrointestinal effects}

Treatment associated gastrointestinal (GI) symptoms (nausea, vomiting, diarrhoea) are well recognised adverse effects of GLP-1RAs and are demonstrated to be higher than with other glucose lowering therapies. 68 Longer-acting GLP-1RAs were associated with a lower risk of GI side effects (with an exception of albiglutide and once-weekly exenatide) compared to short acting GLP-1RAs (EBID, lixisenatide).25,27,50 Of the two short acting GLP-1RAs, lixisenatide demonstrated a lower rate of Gl side effects than EBID. ${ }^{36}$ The risk is also dose related and was found to be greater with the higher dose of liraglutide (3 mg vs $1.8 \mathrm{mg}$ vs $1.2 \mathrm{mg}$ ) in the LEAD studies and the SCALE Diabetes study. 60,64 


\section{Hypoglycaemia}

In all RCTs, the risk of total and severe hypoglycaemia was significantly lower with GLP-1RAs compared to placebo or other glucose lowering therapies. Concomitant use of SU or insulin increased the risk of hypoglycaemia. In a head to head comparison, albiglutide and lixisenatide were shown to have a slightly lower risk than other GLP-1RAs. ${ }^{36,49}$

\section{Pancreatitis and pancreatic cancer}

Based on a small number of case reports and animal studies, there was growing concern about the association between incretin-based therapies and pancreatitis in late 2000.69 Most safety data have been acquired through the FDA adverse event reporting system. A meta-analysis conducted from pooled data of 27 RCTs of GLP-1RAs did not suggest an increased risk of pancreatitis among patients using incretin therapies compared to placebo. ${ }^{70}$ Recently, a large population-based study involving over 12,000 patients hospitalised for acute pancreatitis in Denmark reported that the risk of pancreatitis in people treated with GLP-1RAs remained low and comparable to that of other glucose lowering therapies. ${ }^{71}$ Nauck also argued that there is no firm evidence to suggest that GLP-1RA therapy is associated with an increased risk of malignancy including pancreatic cancer from available pre-clinical and clinical studies. ${ }^{72,73}$ The evaluation of lixisenatide in acute coronary syndrome (ELIXA) study and the Liraglutide Effect and Action in Diabetes: Evaluation of Cardiovascular Outcome Results-A Long Term Evaluation (LEADER) study both reported no increased risk of pancreatitis or pancreatic cancer with lixisenatide and liraglutide. ${ }^{74,75}$ The conclusion was that cardio-metabolic benefits of GLP-1RAs therapy outweigh the risk of pancreatitis or pancreatic cancer. To date, no definite causal relationship has been established between pancreatitis or pancreatic cancer and GLP-1RA therapy but caution needs to be exercised.

\section{Injection site reactions}

Injection site reactions are commonly reported with both daily and once-weekly injections. However, more injection site reactions such as nodules and pruritus are observed with onceweekly exenatide due to the formulation and delivery technology (microspheres) than with dulaglutide or liraglutide. ${ }^{76}$

\section{Cardiovascular safety}

All new drugs for T2DM are required by the FDA to demonstrate cardiovascular safety and currently several GLP-1RAs are undergoing large-scale, long-term trials specifically designed for cardiovascular outcomes. In a meta-analysis, treatment with GLP-1RAs was not associated with an increased risk of cardiovascular events compared to active comparators. ${ }^{77}$ In fact, a significant reduction in the incidence of cardiovascular events was observed in comparison with placebo and pioglitazone. ${ }^{77}$ The first cardiovascular safety study (ELIXA) completed among all GLP-1RAs reported non-inferiority versus placebo for the composite cardiovascular endpoint, thus satisfying the FDA requirements of cardiovascular safety. ${ }^{74}$ However, more recently, the
LEADER trial demonstrated the cardiovascular benefit of liraglutide in high-risk cardiovascular patients with T2DM. ${ }^{75}$ In fact, liraglutide has demonstrated superiority to placebo with a $13 \%$ relative risk reduction in the first occurrence of cardiovascular death, non-fatal myocardial infarction or non-fatal stroke and a $22 \%$ reduction in mortality due to cardiovascular causes. This is the first cardiovascular safety trial among incretin-based therapies that has demonstrated a positive outcome on cardiovascular effect. Other ongoing international RCTs examining cardiovascular safety of GLP-1RAs are once-weekly exenatide (EXSCEL), dulaglutide (REWIND), and semaglutide (SUSTAIN 6).

\section{Combination therapy of insulin and GLP-1RA}

Recently, a fixed-ratio combination of basal insulin degludec and liraglutide (IDegLira) was developed based on complementary therapeutic effects of these agents on FPG and PPG. IDegLira was superior in glycaemic efficacy to liraglutide with lower GI adverse events and non-inferior to degludec with no increased hypoglycaemic events (DUAL I). ${ }^{78}$ Moreover, treatment with IDegLira demonstrated significantly greater $\mathrm{HbA}_{1 \mathrm{c}}$ reduction with fewer hypoglycaemic episodes, lower insulin requirement and weight loss compared to insulin glargine (DUAL V). ${ }^{79}$ Another fixed-ratio combination of basal insulin glargine and lixisenatide (LixiLan) is in development. The proof of concept trial of 24 weeks' duration revealed that adding LixiLan to metformin in insulin naïve patients improved glycaemic control by $1.8 \%$, more than $80 \%$ of the participants achieving $\mathrm{HbA}_{1 \mathrm{c}}<7 \% .80$ This combination is being evaluated in phase 3 trials, which are due to report soon. GLP-1RAs and insulin combinations are therefore particularly advantageous for obese patients with long standing T2DM for mitigating the weight gain associated with insulin therapy, improving glycaemic control and possibly reducing insulin requirement. This advantage may lead to greater adherence and patient satisfaction.

\section{Real life clinical experience of GLP-1 use in the UK}

The Association of British Clinical Diabetologists undertook nationwide audits on the use of EBID and liraglutide in real clinical practice to determine their effects on $\mathrm{HbA}_{1 \mathrm{c}}$, weight, blood pressure and lipids. Data were collected from centres around the UK involving over 6,700 patients for EBID in 2009 and 2,300 for liraglutide in 2011 over 6 months. The baseline $\mathrm{HbA}_{1 \mathrm{c}}$ and $\mathrm{BMI}$ were $9.5 \%$ and $39.8 \mathrm{~kg} / \mathrm{m}^{2}$ for EBID and $9.3 \%$ and $39.1 \mathrm{~kg} / \mathrm{m}^{2}$ for liraglutide. Both baseline $\mathrm{HbA}_{1 \mathrm{c}}$ and $\mathrm{BMI}$ were significantly higher in the audits compared to that in RCTs. By 6 months there were significant reductions in $\mathrm{HbA}_{1 \mathrm{c}}$ and weight of $0.75 \%$ and $6.6 \mathrm{~kg}$ with EBID and $0.93 \%$ and $3.7 \mathrm{~kg}$ with liraglutide. It may appear that treatment with liraglutide resulted in greater $\mathrm{HbA}_{1 \mathrm{c}}$ reduction but less weight loss compared to EBID. However, the authors commented that a major contributing factor was less insulin and TZD discontinuation observed in the liraglutide audit. ${ }^{81}$

At the time of the audit it was recommended by NICE that GLP-1RAs were not to be used with insulin. In both audits, $35-40 \%$ of patients were on combination therapy with insulin and stopping insulin was associated with greater weight reduc- 
tion but lesser improvement in $\mathrm{HbA}_{1 c}$. There was a reduction in insulin dose of $42 \pm 2$ units from baseline of $120 \pm 99$ units with EBID and $16.6 \%$ discontinued insulin. ${ }^{57}$ It was found that GLP1RA treatments were more effective in non-insulin treated patients than in insulin treated patients. ${ }^{82}$ Although approximately $60 \%$ of the patients in both audits achieved reductions in both $\mathrm{HbA}_{1 \mathrm{c}}$ and weight, only $25 \%$ in the liraglutide audit and $29 \%$ in the EBID audit met the NICE criteria of $\mathrm{HbA}_{1 c}$ reduction $\geq 1 \%$ and weight reduction $\geq 3 \%$ to continue GLP-1 treatment. ${ }^{82} \mathrm{Gl}$ side effects were reported to be higher with EBID (24\%) than with liraglutide (16\%). ${ }^{81}$ Both EBID and liraglutide treatment were associated with a reduction in SBP, total cholesterol and triglycerides. ${ }^{82}$

\section{Costs}

The cost of GLP-1 RAs is significantly higher than other agents such as SU, pioglitazone, DPP-4 inhibitors or insulin glargine. Literature on the cost-effectiveness of the use of GLP-1RAs is limited. In a retrospective cohort study of real world data (US), diabetes-related pharmacy costs were greater with liraglutide than with EBID. However, a higher proportion of patients on liraglutide achieved $\mathrm{HbA}_{1 c}<7 \%$, resulting in a lower per-patient cost of $\mathrm{HbA}_{1 c}$ goal achievement with liraglutide compared to EBID. ${ }^{83}$ In the UK, Evan and colleagues conducted a retrospective audit in Wales. Over 1000 patients taking liraglutide, EBID or DPP-4 inhibitors were followed up for a median of 48 weeks. Costs per quality-adjusted life-year were $£ 16,505, £ 16,648$ and f20,661 for liraglutide, exenatide and DPP-4 inhibitors, respectively. ${ }^{84}$ The authors concluded that, when prescribed according to NICE recommendations, incretin-based therapies were cost-effective options, with liraglutide providing greatest $\mathrm{HbA}_{1 c}$ reductions. ${ }^{84}$

Generally, studies that have examined the cost implications of improving glucose management have reported that the glycaemic control costs were modest compared to total diabetesrelated health expenditures. ${ }^{85,86}$ Although some studies reported the acquisition cost, they did not evaluate or relate these findings to outcomes in $\mathrm{HbA}_{1 \mathrm{c}}$ or other compilations due to poor glycaemic control. Consequently, it is very hard to put the costeffectiveness of these new drugs into perspective in the short term and therefore real world evidence has become increasingly important as a decision-making tool for policymakers and health care providers.

\section{Discussion}

GLP-1RAs are a novel class of therapeutic agent used in the management of T2DM. In comparison with other available glucose lowering therapies, GLP-1RAs demonstrate either superiority or non-inferiority in glycaemic efficacy with a favourable effect on body weight and a low risk of hypoglycaemia compared with SU, TZD or insulin. In addition, they appear to have beneficial effects on cardiovascular risk factors with a modest reduction in body weight, blood pressure and lipid profile, although there is an associated small risk of increased heart rate. Although ADA/EASD and NICE guidelines advocate the use of GLP-1RAs as an adjunct therapy to metformin and life style modification, there is no specific guidance as to which GLP-1RAs should be chosen.

It must be acknowledged that there are differences in cardio-metabolic and safety parameters among GLP-1RAs. In addition, other practical aspects such as the frequency of administration (twice daily vs once daily vs once weekly) and the ease with which the device can be used need to be considered from the patient's perspective in choosing a particular agent. Generally, long acting GLP-1RAs are more efficacious in reducing $\mathrm{HbA}_{1 \mathrm{c}}$, have greater effect on FPG, and potentially offer better compliance than short acting GLP-1RAs. Hypoglycaemia risk is low and comparable within the class of agents. All GLP-1RAs have moderate effects in lowering SBP and lipid profile. Of all licensed clinically available GLP-1RAs, dulaglutide, once-weekly exenatide and liraglutide were associated with a greater reduction in $\mathrm{HbA}_{1 \mathrm{c}}$ and FPG compared with EBID; liraglutide having greater weight loss and once-weekly exenatide being better tolerated among the three. ${ }^{87}$

In clinical practice, after initiation of lifestyle modification and metformin therapy, a stepwise approach is adopted in advancing glucose lowering therapies before insulin initiation and intensification. Availability of GLP-1RAs offers an alternative to insulin in appropriate patients. When the glycaemic target is not achieved/maintained with a combination of oral therapies, either basal or prandial insulin is added. According to treat-to-target protocols, therapeutic agents are chosen to address both FPG and PPG. GLP-1RAs are either comparable or superior in efficacy to basal insulin in improving $\mathrm{HbA}_{1 \mathrm{c}}$ with an added benefit of weight loss and lower risk of hypoglycaemia, and therefore offer an alternative option to basal insulin in appropriate circumstances. In addition, short acting GLP-1RAs may have a role when glycaemic control is not adequately achieved with basal insulin. ${ }^{34}$ Although the absolute reduction in $\mathrm{HbA}_{1 \mathrm{c}}$ with the short acting GLP-1RA lixisenatide (0.5-0.8\%) is less than $1 \%$ as recommended by the NICE, it may be particularly applicable in cases where additional postprandial glucose lowering effect and weight loss is desirable after introduction of basal insulin.

\section{Conclusion}

GLP-1RAs are effective glucose lowering agents in managing T2DM with a favourable effect on weight reduction and a low risk of hypoglycaemia. Due to limited availability of studies directly comparing these agents, the choice among GLP-1RAs remains uncertain. A definite answer as to which GLP-1RA would suit a particular patient should be assessed on an individual basis. Of all the GLP-1RAs available to date in the UK, evidence suggests that treatment with once daily liraglutide provides a greater $\mathrm{HbA}_{1 \mathrm{c}}$ and weight reduction and, from the limited evidence available, it is more cost effective than EBID. Moreover, liraglutide is the very first GLP-1RA to demonstrate a positive cardiovascular benefit according to the LEADER study recently published. Currently, the choice is left to clinical judgment based on patient factors, preferences and experience of the clinician. Taking all the safety and efficacy factors into ac- 


\section{Key messages}

- GLP-1RAs, a novel class of therapeutic agent, are efficacious in improving glycaemic control with the benefit of weight loss in management of overweight/obese patients with T2DM

- Risk of hypoglycaemia is relatively low unless used in combination with SU or insulin

- Gastrointestinal side effects are common.

- Although no definite casual relationship has been established between pancreatitis/pancreatic cancer with GLP-1RA, caution should be exercised especially in high risk patients

- Lixisenatide demonstrated non-inferiority (ELIXA study) and liraglutide, superiority (LEADER study) to placebo in CV safety studies

count, the choice should be individualised according to patient factors such as weight gain, hypoglycaemic risk, associated comorbidities, frequency of injection, and tolerability of the medication. All in all, the question should not be whether one GLP-1RA is superior but instead whether individual GLP-1RA therapy is superior in a particular patient. Personalising GLP-1RA therapy to particular patients will allow effective glycaemic control while avoiding or minimising adverse effects with potentially better adherence to therapy.

Acknowledgements The authors acknowledge support from the National Institute for Health Research Collaboration for Leadership in Applied Health Research and Care - East Midlands (NIHR CLAHRC - EM), the Leicester Clinical Trials Unit and the NIHR Leicester-Loughborough Diet, Lifestyle and Physical Activity Biomedical Research Unit, which is a partnership between University Hospitals of Leicester NHS Trust, Loughborough University and the University of Leicester. The views expressed are those of the authors and not necessarily those of the NHS, the NIHR or the Department of Health.

Conflicts of interest MD has acted as consultant, advisory board member and speaker for Novo Nordisk, Sanofi-Aventis, Lilly, Merck Sharp \& Dohme, Boehringer Ingelheim, AstraZeneca and Janssen and as a speaker for Mitsubishi Tanabe Pharma Corporation. She has received grants in support of investigator and investigator initiated trials from Novo Nordisk, Sanofi-Aventis and Lilly.

KK has acted as a consultant and speaker for AstraZeneca, Novartis, Novo Nordisk, Sanofi-Aventis, Lilly, Merck Sharp \& Dohme, Janssen and Boehringer Ingelheim. He has received grants in support of investigator and investigator initiated trials from AstraZeneca, Novartis, Novo Nordisk, Sanofi-Aventis, Lilly, Boehringer Ingelheim and Merck Sharp \& Dohme and Roche. KK has served on advisory boards for AstraZeneca, Novartis, Novo Nordisk, Sanofi-Aventis, Lilly, Merck Sharp \& Dohme, Janssen and Boehringer Ingelheim.

SC has received speaker fees and educational funding from Janssen, Novo Nordisk and Sanofi-Aventis.

FZ has no conflict of interest.

$\mathrm{ZZH}$ has received speaker honorary fee and educational funding from Janssen, Eli Lilly, Novo Nordisk, and Boehringer Ingelheim.

\section{References}

1. Defronzo RA. Banting Lecture. From the triumvirate to the ominous octet: a new paradigm for the treatment of type 2 diabetes mellitus. Diabetes 2009;58:773-95. http://dx.doi.org/10.2337/db09-9028

2. Wysham $\mathrm{CH}$. New perspectives in type 2 diabetes, cardiovascular risk, and treatment goals. Postgrad Med 2010;122:52-60. http://dx.doi.org/10.3810/pgm.2010.05.2142

3. Creutzfeldt W, Ebert R. New developments in the incretin concept. Diabetologia 1985;28:565-73. http://dx.doi.org/10.1007/BF00281990

4. Nauck MA, Stockmann F, Ebert R, Creutzefldt W. Reduced incretin effect in type 2 (non-insulin-dependent) diabetes. Diabetologia 1986;29:4652. http://dx.doi.org/10.1007/BF02427280

5. Nauck MA, Vardili F, Deacon CF, Holst JJ, Meier JJ. Secretion of glucagon like peptide-1 (GLP-1) in type 2 diabetes:what is up and what is down? Diabetologia 2011;54:10-8. http://dx.doi.org/10.1007/s00125-010-1896-4

6. Rosenstock J, Balas B, Charbonnel B, et al. The fate of taspoglutide, a weekly GLP-1 receptor agonist, versus twice-daily exenatide for type 2 diabetes. Diabetes Care 2013;36:498-504. http://dx.doi.org/10.2337/dc12-0709

7. Inzucchi SE, Bergenstal RM, Buse JB, et al. Management of hyperglycaemia in type 2 diabetes, 2015: a patient-centred approach. Update to a position statement of the American Diabetes Association and the European Association for the Study of Diabetes. Diabetologia 2015;58: 429-42. http://dx.doi.org/10.1007/s00125-014-3460-0

8. DeFronzo RA, Ratner RE, Han J, Kim DD, Fineman MS, Baron AD. Effects of exenatide (exendin-4) on glycemic control and weight over 30 weeks in metformin-treated patients with type 2 diabetes. Diabetes Care 2005; 28:1092-100. http://dx.doi.org/10.2337/diacare.28.5.1092

9. Buse JB, Henry RR, Han J, Kim DD, Fineman MS, Baron AD. Effects of exenatide (exendin-4) on glycemic control over 30 weeks in sulfonylureatreated patients with type 2 diabetes. Diabetes Care 2004;27:2628-35. http://dx.doi.org/10.2337/diacare.27.11.2628

10. Kendall DM, Riddle MC, Rosenstock J, et al. Effects of exenatide (exendin-4) on glycemic control over 30 weeks in patients with type 2 diabetes treated with metformin and a sulfonylurea. Diabetes Care 2005 28:1083-91. http://dx. doi.org/10.2337/diacare.28.5.1083

11. Liutkus J, Rosas Guzman J, PNorwood P, et al. A placebo-controlled trial of exenatide twice daily added to thiazolidinediones alone or combination with metformin. Diabetes Obes Metab 2010;12:1058-65.

12. Moretto TJ, Milton DR, Ridge TD, et al. Efficacy and tolerability of exenatide monotherapy over 24 weeks in antidiabetic drug-naive patients with type 2 diabetes: a randomized, double-blind, placebo-controlled, parallel-group study. Clin Ther 2008;30:1448-60. http://dx.doi.org/10.1016/j.clinthera.2008.08.006

13. Apovian CM, Bergenstal RM, Cuddihy RM, et al. Effects of exenatide combined with lifestyle modification in patients with type 2 diabetes. Am J Med 2010;123:468.e9-17. http://dx.doi.org/10.1016/j.amjmed.2009.11.019

14. Heine RJ, Van Gaal LF, Johns D, et al. Exenatide versus insulin glargine in patients with suboptimally controlled type 2 diabetes: a randomized trial.[Summary for patients in Ann Intern Med 2005;143:I30; PMID: 16230718]. Ann Intern Med 2005;143:559-69. http://dx.doi.org/10.7326/0003-4819-143-8-200510180-00006

15. Nauck MA, Duran S, Kim D, et al. A comparison of twice-daily exenatide and biphasic insulin aspart in patients with type 2 diabetes who were suboptimally controlled with sulfonylurea and metformin: a non-inferiority study. Diabetologia 2007;50:259-67. http://dx.doi.org/10.1007/s00125-006-0510-2

16. Barnett $A H$, Burger J, Johns D, et al. Tolerability and efficacy of exenatide and titrated insulin glargine in adult patients with type 2 diabetes previously uncontrolled with metformin or a sulfonylurea: a multinational, randomized, open-label, two-period, crossover noninferiority trial. Clin Ther 2007;29:2333-48. http://dx.doi.org/10.1016/j.clinthera.2007.11.006

17. Davies MJ, Donnelly R, Barnett AH, Jones S, Nicolay C, Kilcoyne A. Exenatide compared with long acting insulin to achieve glycaemic control with minimal weight gain in patients with type 2 diabetes mellitus: Results of the Helping Evaluate Exenatide in patients with diabetes compared to LongActing insulin (HEELA) study. Diabetologia 2009;52(S1): \$290. 
18. Buse JB, Bergenstal RM, Glass LC, et al. Use of twice-daily exenatide in basal insulin-treated patients with type 2 diabetes: a randomized, controlled trial. Ann Intern Med 2011;154:103-12. http://dx.doi.org/10.7326/0003-4819-154-2-201101180-00300

19. Bunck MC, Diamant M, Corner A, et al. One-year treatment with exenatide improves beta-cell function, compared with insulin glargine, in metformin-treated type 2 diabetic patients: a randomized, controlled trial. Diabetes Care 2009;32:762-8. http://dx.doi.org/10.2337/dc08-1797

20. Marre M, Shaw J, Brandle M, et al. Liraglutide, a once-daily human GLP1 analogue, added to a sulphonylurea over 26 weeks produces greater improvements in glycaemic and weight control compared with adding rosiglitazone or placebo in subjects with Type 2 diabetes (LEAD-1 SU). Diabet Med 2009;26:268-78. http://dx.doi.org/10.1111/j.1464-5491.2009.02666.x

21. Nauck M, Frid A, Hermansen K, et al. Efficacy and safety comparison of liraglutide, glimepiride, and placebo, all in combination with metformin, in type 2 diabetes: the LEAD (liraglutide effect and action in diabetes)-2 study. Diabetes Care 2009:32:84-90. http://dx.doi.org/10.2337/dc08-1355

22. Garber A, Henry R, Ratner R, et al. Liraglutide versus glimepiride monotherapy for type 2 diabetes (LEAD-3 Mono): a randomised, 52week, phase III, double-blind, parallel-treatment trial. Lancet 2009; 373:473-81. http://dx.doi.org/10.1016/S0140-6736(08)61246-5

23. Zinman B, Gerich J, Buse JB, et al. Efficacy and safety of the human glucagon-like peptide-1 analog liraglutide in combination with metformin and thiazolidinedione in patients with type 2 diabetes (LEAD-4 Met+TZD). Diabetes Care 2009;32:1224-30. http://dx.doi.org/10.2337/dc08-2124

24. Russell-Jones D, Vaag A, Schmitz $O$, et al. Liraglutide vs insulin glargine and placebo in combination with metformin and sulfonylurea therapy in type 2 diabetes mellitus (LEAD-5 met+SU): a randomised controlled trial. Diabetologia 2009;52:2046-55. http://dx.doi.org/10.1007/s00125-009-1472-y

25. Buse JB, Rosenstock J, Sesti G, et al. Liraglutide once a day versus exenatide twice a day for type 2 diabetes: a 26-week randomised, parallelgroup, multinational, open-label trial (LEAD-6). Lancet 2009;374:39-47. http://dx.doi.org/10.1016/\$0140-6736(09)60659-0

26. Pratley RE, Nauck M, Bailey $T$, et al. Liraglutide versus sitagliptin for patients with type 2 diabetes who did not have adequate glycaemic control with metformin: a 26-week, randomised, parallel-group, open-label trial. Lancet 2010;375:1447-56. http://dx.doi.org/10.1016/S0140-6736(10)60307-8

27. Drucker DJ, Buse JB, Taylor K, et al. Exenatide once weekly versus twice daily for the treatment of type 2 diabetes: a randomised, open-label, non-inferiority study. Lancet 2008;372:1240-50. http://dx.doi.org/10.1016/S0140-6736(08)61206-4

28. Bergenstal RM, Wysham C, Macconell L, et al. Efficacy and safety of exenatide once weekly versus sitagliptin or pioglitazone as an adjunct to metformin for treatment of type 2 diabetes (DURATION-2): a randomised trial. Lancet 2010;376:431-9

29. Diamant M, Van Gaal L, Stranks S, et al. Once weekly exenatide compared with insulin glargine titrated to target in patients with type 2 diabetes (DURATION-3): an open-label randomised trial. Lancet 2010;375:2234-43. http://dx.doi.org/10.1016/S0140-6736(10)60406-0

30. Russell-Jones D, Cuddihy RM, Hanefeld M, et al. Efficacy and safety of exenatide once weekly versus metformin, pioglitazone, and sitagliptin used as monotherapy in drug-naive patients with type 2 diabetes (DURATION-4): A 26-week double-blind study. Diabetes Care 2012:35:252-8. http://dx.doi.org/10.2337/dc11-1107

31. Blevins T, Pullman J, Malloy J, et al. DURATION-5: exenatide once weekly resulted in greater improvements in glycemic control compared with exenatide twice daily in patients with type 2 diabetes. J Clin Endocrinol Metab 2011:96:1301-10. http://dx.doi.org/10.1210/jc.2010-2081

32. Buse JB, Nauck $M$, Forst $T$, et al. Exenatide once weekly versus liraglutide once daily in patients with type 2 diabetes (DURATION-6): a randomised, open-label study. Lancet 2013;381:117-24. http://dx.doi.org/10.1016/\$0140-6736(12)61267-7

33. Fonseca VA, Alvarado-Ruiz R, Raccah D, Boka G, Miossec P, Gerich JE. Efficacy and safety of the once-daily GLP-1 receptor agonist lixisenatide in monotherapy: a randomized, double-blind, placebo-controlled trial in patients with type 2 diabetes (GetGoal-Mono). Diabetes Care 2012 35:1225-31. http://dx.doi.org/10.2337/dc11-1935

34. Riddle MC, Forst $\mathrm{T}$, Aronson $\mathrm{R}$, et al. Adding once-daily lixisenatide for type 2 diabetes inadequately controlled with newly initiated and continuously titrated basal insulin glargine: a 24-week, randomized, placebo-controlled study (GetGoal-Duo 1). Diabetes Care 2013;36 2497-503. http://dx.doi.org/10.2337/dc12-2462

35. Bolli GB, Munteanu M, Dotsenko S, et al. Efficacy and safety of lixisenatide once daily vs. placebo in people with Type 2 diabetes insufficiently controlled on metformin (GetGoal-F1). Diabet Med 2014:31:176-84 http://dx.doi.org/ 10.1111/dme.12328

36. Rosenstock J, Raccah D, Koranyi L, et al. Efficacy and safety of lixisenatide once daily versus exenatide twice daily in type 2 diabetes inadequately controlled on metformin: a 24-week, randomized, open-label, active-controlled study (GetGoal-X). Diabetes Care 2013;36:2945-51. http://dx.doi.org/10.2337/dc12-2709

37. Rosenstock J, Hanefeld M, Shamanna P, et al. Beneficial effects of oncedaily lixisenatide on overall and postprandial glycemic levels without significant excess of hypoglycemia in type 2 diabetes inadequately controlled on a sulfonylurea with or without metformin (GetGoal-S). J Diabetes Complications 2014:28:386-92. http://dx.doi.org/10.1016/j.jdiacomp.2014.01.012

38. Pinget M, Goldenberg R, Niemoeller E, Muehlen-Bartmer I, Guo H, Aronson R. Efficacy and safety of lixisenatide once daily versus placebo in type 2 diabetes insufficiently controlled on pioglitazone (GetGoal-P). Diabetes Obes Metab 2013;15:1000-07. http://dx.doi.org/10.1111/dom.12121

39. Ahren B, Leguizamo Dimas A, Miossec P, Saubadu S, Aronson R. Efficacy and safety of lixisenatide once-daily morning or evening injections in type 2 diabetes inadequately controlled on metformin (GetGoal-M). Diabetes Care 2013;36:2543-50. http://dx.doi.org/10.2337/dc12-2006

40. Yu Pan C, Han P, Liu X, et al. Lixisenatide treatment improves glycaemic control in Asian patients with type 2 diabetes mellitus inadequately controlled on metformin with or without sulfonylurea: a randomized, double-blind, placebo-controlled, 24-week trial (GetGoal-M-Asia). Diabetes Metab Res Rev 2014;30:726-35. http://dx.doi.org/10.1002/dmrr.2541

41. Riddle MC, Aronson R, Home $\mathrm{P}$, et al. Adding once-daily lixisenatide for type 2 diabetes inadequately controlled by established basal insulin: a 24-week, randomized, placebo-controlled comparison (GetGoal-L). Diabetes Care 2013;36:2489-96. http://dx.doi.org/10.2337/dc12-2454

42. Seino Y, Min KW, Niemoeller E, Takami A. Randomized, double-blind, placebo-controlled trial of the once-daily GLP-1 receptor agonist lixisenatide in Asian patients with type 2 diabetes insufficiently controlled on basal insulin with or without a sulfonylurea (GetGoal-L-Asia). Diabetes Obes Metab 2012:14:910-17.

http://dx.doi.org/10.1111/j.1463-1326.2012.01618.x

43. Reusch J, Stewart MW, Perkins CM, et al. Efficacy and safety of onceweekly glucagon-like peptide 1 receptor agonist albiglutide (HARMONY 1 trial): 52-week primary endpoint results from a randomized, doubleblind, placebo-controlled trial in patients with type 2 diabetes mellitus not controlled on pioglitazone, with or without metformin. Diabetes Obes Metab 2014;161257-64.

44. Nauck MA, Stewart MW, Perkins $C$, et al. Efficacy and safety of onceweekly GLP-1 receptor agonist albiglutide (HARMONY 2): 52 week primary endpoint results from a randomised, placebo-controlled trial in patients with type 2 diabetes mellitus inadequately controlled with diet and exercise. Diabetologia 2016:59:266-74.

45. Ahren B, Johnson SL, Stewart M, et al. HARMONY 3: 104-week randomized, double-blind, placebo- and active-controlled trial assessing the efficacy and safety of albiglutide compared with placebo, sitagliptin, and glimepiride in patients with type 2 diabetes taking metformin. Diabetes Care 2014:37:2141-8. http://dx.doi.org/10.2337/dc14-0024

46. Weissman PN, Carr MC, Ye J, et al. HARMONY 4: randomised clinical trial comparing once-weekly albiglutide and insulin glargine in patients with type 2 diabetes inadequately controlled with metformin with or without sulfonylurea. Diabetologia 2014;57:2475-84. http://dx.doi.org/10.1007/s00125-014-3360-3

47. Home PD, Shamanna P, Stewart M, et al. Efficacy and tolerability of albiglutide versus placebo or pioglitazone over 1 year in people with type 2 diabetes currently taking metformin and glimepiride: HARMONY 5. Diabetes Obes Metab 2015;17:179-87. 
http://dx.doi.org/10.1111/dom.12414

48. Rosenstock J, Fonseca VA, Gross JL, et al. Advancing basal insulin replacement in type 2 diabetes inadequately controlled with insulin glargine plus oral agents: a comparison of adding albiglutide, a weekly GLP-1 receptor agonist, versus thrice-daily prandial insulin lispro. Diabetes Care 2014;37:2317-25. http://dx.doi.org/10.2337/dc14-0001

49. Pratley RE, Nauck MA, Barnett AH, et al. Once-weekly albiglutide versus once-daily liraglutide in patients with type 2 diabetes inadequately controlled on oral drugs (HARMONY 7): a randomised, open-label, multicentre, non-inferiority phase 3 study. Lancet Diabetes Endocrinol 2014; 2:289-97. http://dx.doi.org/10.1016/S2213-8587(13)70214-6

50. Wysham C, Blevins T, Arakaki R, et al. Efficacy and safety of dulaglutide added onto pioglitazone and metformin versus exenatide in type 2 diabetes in a randomized controlled trial (AWARD-1). Diabetes Care 2014; 37:2159-67. http://dx.doi.org/10.2337/dc13-2760

51. Giorgino F, Benroubi M, Sun JH, Zimmermann AG, Pechtner V. Efficacy and safety of once-weekly dulaglutide versus insulin glargine in patients with type 2 diabetes on metformin and glimepiride (AWARD-2). Diabetes Care 2015;38:2241-9. http://dx. doi.org/10.2337/dc14-1625

52. Umpierrez G, Tofe Povedano S, Perez Manghi F, Shurzinske L, Pechtner $\checkmark$. Efficacy and safety of dulaglutide monotherapy versus metformin in type 2 diabetes in a randomized controlled trial (AWARD-3). Diabetes Care 2014;37:2168-76. http://dx.doi.org/10.2337/dc13-2759

53. Blonde L, Jendle J, Gross J, et al. Once-weekly dulaglutide versus bedtime insulin glargine, both in combination with prandial insulin lispro, in patients with type 2 diabetes (AWARD-4): a randomised, open-label, phase 3, noninferiority study. Lancet 2015;385:2057-66. http://dx.doi.org/10.1016/S0140-6736(15)60936-9

54. Nauck M, Weinstock RS, Umpierrez GE, Guerci B, Skrivanek Z, Milicevic Z. Efficacy and safety of dulaglutide versus sitagliptin after 52 weeks in type 2 diabetes in a randomized controlled trial (AWARD-5). Diabetes Care 2014;37:2149-58. http://dx.doi.org/10.2337/dc13-2761

55. Dungan KM, Povedano ST, Forst T, et al. Once-weekly dulaglutide versus once-daily liraglutide in metformin-treated patients with type 2 diabetes (AWARD-6): a randomised, open-label, phase 3, non-inferiority trial. Lancet 2014:384:1349-57. http://dx.doi.org/10.1016/S0140-6736(14)60976-4

56. Yoon NM, Cavaghan MK, Brunell RL, Roach P. Exenatide added to insulin therapy: a retrospective review of clinical practice over two years in an academic endocrinology outpatient setting. Clinical therapeutics 2009;31:1511-23. http://dx.doi.org/10.1016/j.clinthera.2009.07.021

57. Thong KY, Jose B, Sukumar N, et al. Safety, efficacy and tolerability of exenatide in combination with insulin in the Association of British Clinical Diabetologists nationwide exenatide audit. Diabetes Obes Metab 2011; 13:703-10. http://dx.doi.org/10.1111/j.1463-1326.2011.01393.x

58. Nauck M, Rizzo M, Piraga V, Bosch-Traberg H, Madsen J, Cariou B. Oncedaily liraglutide vs lixsenatide as add-on to metformin in type 2 diabetes: a 26-week randomised controlled clinical trial. EASD Annual Meeting; Stockholm; 2015.

59. Linnebjerg $\mathrm{H}$, Kothare PA, Skrivanek $Z$, et al. Exenatide: effect of injection time on postprandial glucose in patients with Type 2 diabetes. Diabet Med 2006;23:240-5. http://dx.doi.org/10.1111/j.1464-5491.2006. 01800.x

60. Blonde L, Russell-Jones D. The safety and efficacy of liraglutide with or without oral antidiabetic drug therapy in type 2 diabetes: an overview of the LEAD 1-5 studies. Diabetes Obes Metab 2009;11(Suppl 3):26-34. $\mathrm{http}: / / \mathrm{dx}$.doi.org/10.1111/j.1463-1326.2009.01075.x

61. Meier JJ, Rosenstock J, Hincelin-Mery A, et al. Contrasting effects of lixisenatide and liraglutide on postprandial glycemic control, gastric emptying, and safety parameters in patients with type 2 diabetes on optimized insulin glargine with or without metformin: a randomized, open-label trial. Diabetes Care 2015;38:1263-73. http://dx.doi.org/10.2337/dc14-1984

62. Potts JE, Gray LJ, Brady EM, Khunti K, Davies MJ, Bodicoat DH. The effect of glucagon-like peptide 1 receptor agonists on weight loss in type 2 diabetes: a systematic review and mixed treatment comparison metaanalysis. PLoS one 2015;10:e0126769.

http://dx.doi.org/10.1371/journal.pone.0126769

63. Ahren B, Johnson SL, Stewart M, et al. HARMONY 3: 104-week randomized, double-blind, placebo- and active-controlled trial assessing the efficacy and safety of albiglutide compared with placebo, sitagliptin, and glimepiride in patients with type 2 diabetes taking metformin. Diabetes Care 2014;37:2141-8. http://dx.doi.org/10.2337/dc14-0024

64. Davies MJ, Bergenstal R, Bode B, et al. Efficacy of liraglutide for weight loss among patients with type 2 diabetes: The scale diabetes randomized clinical trial. JAMA 2015:314:687-99. http://dx.doi.org/10.1001/jama.2015.9676

65. Pi-Sunyer $X$, Astrup A, Fujioka K, et al. A randomized, controlled trial of $3.0 \mathrm{mg}$ of liraglutide in weight management. N Engl J Med 2015; 373:11-22. http://dx.doi.org/10.1056/NEJMoa1411892

66. Robinson LE, Holt TA, Rees K, Randeva HS, O'Hare JP. Effects of exenatide and liraglutide on heart rate, blood pressure and body weight: systematic review and meta-analysis. BMJ Open 2013;3:e001986. http://dx.doi.org/10.1136/bmjopen-2012-001986

67. Sun F, Wu S, Wang J, et al. Effect of glucagon-like peptide-1 receptor agonists on lipid profiles among type 2 diabetes: a systematic review and network meta-analysis. Clin Ther 2015;37:225-41.e8 http://dx.doi.org/10.1016/j.clinthera.2014.11.008

68. Sun F, Chai S, Yu K, et al. Gastrointestinal adverse events of glucagonlike peptide-1 receptor agonists in patients with type 2 diabetes: a systematic review and network meta-analysis. Diabetes Technol Ther 2015;17:35-42.vhttp://dx.doi.org/10.1089/dia.2014.0188

69. Butler PC, Elashoff M, Elashoff R, Gale EA. A critical analysis of the clinical use of incretin-based therapies: Are the GLP-1 therapies safe? Diabetes Care 2013;36:2118-25. http://dx.doi.org/10.2337/dc12-2713

70. Li L, Shen J, Bala MM, et al. Incretin treatment and risk of pancreatitis in patients with type 2 diabetes mellitus: systematic review and meta-analysis of randomised and non-randomised studies. BMJ 2014;348:g2366. http://dx.doi.org/10.1136/bmj.g2366.

71. Thomsen RW, Pedersen L, Moller N, Kahlert J, Beck-Nielsen H, Sorensen $\mathrm{HT}$. Incretin-based therapy and risk of acute pancreatitis: a nationwide population-based case-control study. Diabetes Care 2015;38:1089-98. http://dx.doi.org/10.2337/dc13-2983

72. Nauck MA. A critical analysis of the clinical use of incretin-based therapies: The benefits by far outweigh the potential risks. Diabetes Care 2013:36:2126-32. http://dx.doi.org/10.2337/dc12-2504

73. Nauck MA, Friedrich N. Do GLP-1-based therapies increase cancer risk? Diabetes Care 2013;36(Suppl2):S245-52. http://dx.doi.org/10.2337/dcS13-2004

74. Pfeffer MA, Claggett B, Diaz R, et al. Lixisenatide in patients with type 2 diabetes and acute coronary syndrome. N Engl J Med 2015;373:224757. http://dx.doi.org/10.1056/NEJMoa1509225

75. Marso SP, Daniels GH, Brown-Frandsen K, et al. Liraglutide and cardiovascular outcomes in type 2 diabetes. N Engl J Med 2016;375:311-22. http://dx.doi.org/10.1056/NEJMoa1603827

76. Karagiannis T, Liakos A, Bekiari $\mathrm{E}$, et al. Efficacy and safety of onceweekly glucagon-like peptide 1 receptor agonists for the management of type 2 diabetes: a systematic review and meta-analysis of randomized controlled trials. Diabetes Obes Metab 2015;17:1065-74. http://dx.doi.org/10.1111/dom.12541

77. Monami M, Dicembrini I, Nardini C, Fiordelli I, Mannucci E. Effects of glucagon-like peptide-1 receptor agonists on cardiovascular risk: a metaanalysis of randomized clinical trials. Diabetes Obes Metab 2014;16:3847. http://dx.doi.org/10.1111/dom.12175

78. Gough SC, Bode B, Woo V, et al. Efficacy and safety of a fixed-ratio combination of insulin degludec and liraglutide (IDegLira) compared with its components given alone: results of a phase 3 , open-label, randomised, 26-week, treat-to-target trial in insulin-naive patients with type 2 diabetes. Lancet Diabetes Endocrinol 2014:2:885-93. http://dx.doi.org/10.1016/S2213-8587(14)70174-3

79. Lingvay I, Manghi FP, García-Hernández P, et al. Effect of insulin glargine up-titration vs insulin degludec/liraglutide on glycated hemoglobin levels in patients with uncontrolled type 2 diabetes: The DUAL V Randomized Clinical Trial. JAMA 2016;315:898-907.

80. Rosenstock J, Diamant M, Aroda VR, et al. Efficacy and Safety of LixiLan, a Titratable Fixed-Ratio Combination of Lixisenatide and Insulin Glargine, Versus Insulin Glargine in Type 2 Diabetes Inadequately Controlled on Metformin Monotherapy: The LixiLan Proof-of-Concept Randomized Trial. Diabetes Care 2016:39:1579-86.

81. Ryder RE, Thong KY, Cull ML, Mills AP, Walton C, Wincour PH. Findings 
from the Association of British Clinical Diabetologists ( $A B C D)$ nationwide exenatide and liraglutide audits. Practical Diabetes Inter 2010;27:3527. http://dx.doi.org/10.1002/pdi.1522

82. Thong KY, Gupta PS, Cull ML, et al. GLP-1 receptor agonists in type 2 diabetes - NICE guidelines versus clinical practice. Br J Diabetes Vasc Dis 2014; 14:52-59.

83. DeKoven M, Lee WC, Bouchard J, Massoudi M, Langer J. Real-world cost-effectiveness: lower cost of treating patients to glycemic goal with liraglutide versus exenatide. Adv Ther 2014;31:202-16. http://dx.doi.org/10.1007/s12325-014-0098-8

84. Evans D, McEwans P, O'Shea R, George L. A retrospective, case-note survey of type 2 diabetes patients prescribed incretin-based therapies in clinical practice. Diabetes Therapy 2013;4:27-40 http://dx.doi.org/10.1007/s13300-012-0015-6

85. ADA. Economic costs of diabetes in the U.S. in 2012. Diabetes Care 2013;36(4):1033-46. http://dx.doi.org/10.2337/dc12-2625

86. Stolar MW, Hoogwerf BJ, Gorshow SM, Boyle PJ, Wales DO. Managing type 2 diabetes: going beyond glycemic control. J Manag Care Pharm 2008;14(5 Suppl B):s2-19.

87. Zaccardi F, Htike ZZ, Webb DR, Khunti K, Davies MJ. Benefits and harms of once-weekly glucagon-like peptide-1 receptor agonist treatments: a systematic review and network meta-analysis. Ann Intern Med 2016 164(2):102-13. http://dx.doi.org/10.7326/M15-1432

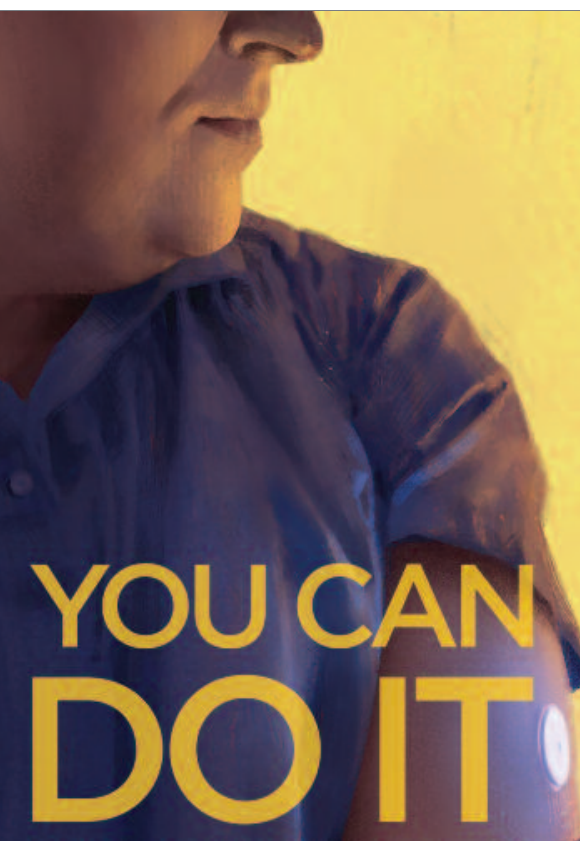

\section{WITHOUT LANCETS}

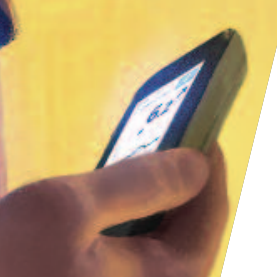

FreeStyle

APPROVED FOR AGES $4+^{\#}$

\section{Liberate your patients from the hassles of glucose monitoring. ${ }^{1}$}

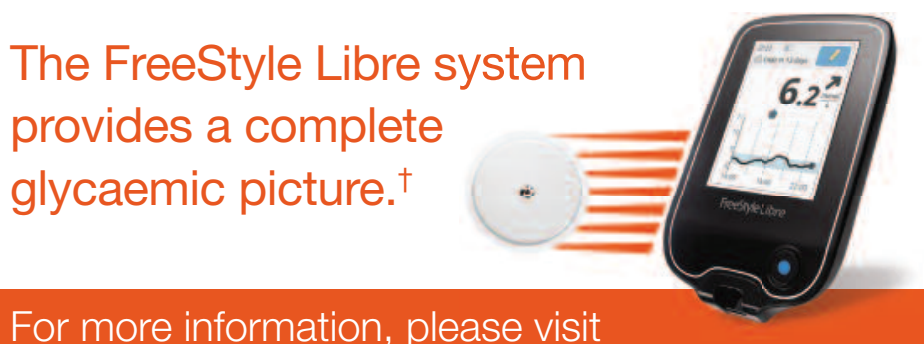

For more information, please visit FreeStyleLibre.co.uk/publications
Scanning the sensor to obtain glucose values does not require lancets.

* The FreeStyle Libre Flash Glucose Monitoring System is indicated for measuring interstitial fluid glucose levels in people (age 4 and older) with diabetes mellitus. The indication for children (age 4 - 17) is limited to those who are supervised by a caregiver who is at least 18 years of age. A caregiver at least 18 years old is responsible for supervising, managing, and assisting the child in using the FreeStyle Libre system and interpreting its readings.

Data on file. Abbott Diabetes Care. The FreeStyle Libre system liberates you from the hassles of glucose monitoring. In a study conducted by Abbott Diabetes Care, $100 \%$ of patients surveyed $(n=23)$ agreed that the FreeStyle Libre system reduces the hassle of glucose monitoring.

† To get a complete glycaemic picture the sensor must be replaced every 14 days and the sensor must be scanned at least once every 8 hours.

FreeStyle and related brand marks are trademarks

of Abbott Diabetes Care Inc, in various jurisdictions.

Simulated data for illustrative purposes only;

not real patient or data.

Date of preparation: July 2016. ADCMDP160092

Abbott 


\section{Appendix 1 - Supplementary Table S1}

Summary of randomised controlled trials (RCTs) of exenatide (ExBID)

\begin{tabular}{|c|c|c|c|c|c|c|c|c|c|}
\hline $\begin{array}{l}\text { Study } \\
\text { (RCT) }\end{array}$ & $\begin{array}{l}\text { Duration of } \\
\text { the study } \\
\text { (weeks) }\end{array}$ & $\begin{array}{c}\text { Background } \\
\text { therapy }\end{array}$ & $\begin{array}{c}\text { Comparato } \\
\mathbf{r}\end{array}$ & $\begin{array}{c}\text { Baseline } \\
\text { HbA1c(\%) }\end{array}$ & $\begin{array}{c}\text { Difference } \\
\text { in HbA1c } \\
(\%) \\
\text { vs } \\
\text { comparator }\end{array}$ & $\begin{array}{c}\text { Difference } \\
\text { in FPG } \\
(\mathrm{mmol} / \mathrm{L}) \\
\text { vs } \\
\text { comparator }\end{array}$ & $\begin{array}{c}\text { Difference } \\
\text { in body } \\
\text { weight (kg) } \\
\text { vs } \\
\text { comparator }\end{array}$ & $\begin{array}{c}\text { Difference } \\
\text { in SBP } \\
(\mathrm{mmHg}) \\
\text { vs } \\
\text { comparator }\end{array}$ & $\begin{array}{c}\text { Difference } \\
\text { in Total } \\
\text { Cholesterol } \\
(\mathrm{mmol} / \mathrm{L}) \\
\text { vs } \\
\text { comparator }\end{array}$ \\
\hline $\begin{array}{c}\text { De Fronzo } \\
(2005)\end{array}$ & 30 & MF & Placebo & $8.2 \pm 1.1$ & $\begin{array}{c}-0.8 \\
(<0.002)\end{array}$ & $\begin{array}{c}-1.4 \\
(0.0001)\end{array}$ & $\begin{array}{c}-2.5 \\
(<0.05)\end{array}$ & Not stated & Not stated \\
\hline $\begin{array}{l}\text { Buse } \\
(2004)\end{array}$ & 30 & $\mathrm{SU}$ & Placebo & 8.6 & $\begin{array}{c}-0.8 \\
(<0.002)\end{array}$ & $\begin{array}{c}-1.0 \\
(\leq 0.05)\end{array}$ & $\begin{array}{c}-1.0 \\
(<0.05)\end{array}$ & Not stated & Not stated \\
\hline $\begin{array}{l}\text { Kendall } \\
(2005)\end{array}$ & 30 & $\mathrm{MF}+\mathrm{SU}$ & Placebo & 8.5 & $\begin{array}{c}-1.0 \\
(<0.0001)\end{array}$ & $\begin{array}{c}-1.4 \\
(<0.0001)\end{array}$ & $\begin{array}{c}-0.7 \\
(\leq 0.01)\end{array}$ & Not stated & Not stated \\
\hline $\begin{array}{l}\text { Liutkus } \\
\text { (2010) }\end{array}$ & 26 & $\mathrm{TZD} \pm \mathrm{MF}$ & Placebo & 8.2 & $\begin{array}{c}-0.8 \\
(<0.001)\end{array}$ & $\begin{array}{c}-1.0 \\
(0.009)\end{array}$ & $\begin{array}{c}\text { No } \\
\text { significant } \\
\text { difference }\end{array}$ & $\begin{array}{c}\text { No } \\
\text { significant } \\
\text { difference }\end{array}$ & $\begin{array}{c}\text { No } \\
\text { significant } \\
\text { difference }\end{array}$ \\
\hline $\begin{array}{l}\text { Moretto } \\
(2008)\end{array}$ & 24 & None & Placebo & 7.8 & $\begin{array}{c}-1.1 \\
(<0.001)\end{array}$ & $\begin{array}{c}-0.7 \\
(0.02)\end{array}$ & $\begin{array}{c}-1.7 \\
(<0.001)\end{array}$ & $\begin{array}{c}-2.3 \\
(0.05)\end{array}$ & Not stated \\
\hline $\begin{array}{c}\text { Apovian } \\
\text { (2010) }\end{array}$ & 24 & Lifestyle & Placebo & 7.6 & $\begin{array}{c}-0.5 \\
(<0.0001)\end{array}$ & Not stated & $\begin{array}{c}-6.2 \\
(0.03)\end{array}$ & $\begin{array}{c}-7.5 \\
(<0.001)\end{array}$ & Not stated \\
\hline $\begin{array}{l}\text { Heine } \\
(2005)\end{array}$ & 26 & $\mathrm{MF}+\mathrm{SU}$ & Glargine & 8.2 & $\begin{array}{c}\text { No } \\
\text { significant } \\
\text { difference }\end{array}$ & $\begin{array}{c}1.5 \\
(<0.001)\end{array}$ & $\begin{array}{c}-4.1 \\
(<0.0001)\end{array}$ & Not stated & Not stated \\
\hline $\begin{array}{l}\text { Nauck } \\
(2007)\end{array}$ & 26 & $\mathrm{MF}+\mathrm{SU}$ & $\begin{array}{l}\text { Insulin } \\
\text { aspart }\end{array}$ & 8.6 & $\begin{array}{c}\text { No } \\
\text { significant } \\
\text { difference }\end{array}$ & Not stated & $-5.1(<0.001)$ & Not stated & Not stated \\
\hline $\begin{array}{c}\text { Barnett } \\
(2007)\end{array}$ & 32 & MF or SU & Glargine & 8.9 & $\begin{array}{c}\text { No } \\
\text { significant } \\
\text { difference }\end{array}$ & $\begin{array}{c}1.2 \\
(<0.001)\end{array}$ & $\begin{array}{c}-2.2 \\
(<0.001)\end{array}$ & Not stated & Not stated \\
\hline $\begin{array}{l}\text { Davies } \\
(2009)\end{array}$ & 26 & $\begin{array}{c}\text { MF } \\
\pm \mathrm{SU} / \mathrm{TZD}\end{array}$ & Glargine & 8.7 & $\begin{array}{c}\text { No } \\
\text { significant } \\
\text { difference }\end{array}$ & $\begin{array}{c}1.1 \\
(<0.001)\end{array}$ & $\begin{array}{c}-5.7 \\
(<0.001)\end{array}$ & $\begin{array}{c}-2.2 \\
(0.03)\end{array}$ & $\begin{array}{c}-0.2 \\
(0.12)\end{array}$ \\
\hline $\begin{array}{c}\text { Buse } \\
(2011)\end{array}$ & 30 & $\begin{array}{c}\text { Glargine } \pm \\
\text { MF/TZD }\end{array}$ & Placebo & 8.4 & $\begin{array}{c}-0.7 \\
(<0.001)\end{array}$ & NS & $\begin{array}{c}-2.74 \\
(<0.001)\end{array}$ & $\begin{array}{c}-4.4 \\
(0.01)\end{array}$ & $\begin{array}{c}\text { No } \\
\text { significant } \\
\text { difference }\end{array}$ \\
\hline $\begin{array}{l}\text { Bunck } \\
\text { (2009) }\end{array}$ & 52 & MF & Glargine & 7.5 & $\begin{array}{c}\text { No } \\
\text { significant } \\
\text { difference }\end{array}$ & Not stated & $\begin{array}{c}-4.6 \\
(0.0001)\end{array}$ & Not stated & Not stated \\
\hline
\end{tabular}


Appendix 1 - Supplementary Table S2

Summary of randomised controlled trials (RCTS) of liraglutide (LEAD studies)

\begin{tabular}{|c|c|c|c|c|c|c|c|c|c|}
\hline $\begin{array}{l}\text { Study } \\
\text { (RCT) }\end{array}$ & $\begin{array}{c}\text { Duration of } \\
\text { the study } \\
\text { (weeks) }\end{array}$ & $\begin{array}{c}\text { Background } \\
\text { therapy }\end{array}$ & Comparator & $\begin{array}{c}\text { Baseline } \\
\text { HbA1C (\%) }\end{array}$ & $\begin{array}{c}\text { Difference } \\
\text { in HbA1c } \\
(\%) \\
\text { vs } \\
\text { comparator }\end{array}$ & $\begin{array}{c}\text { Difference } \\
\text { in FPG } \\
(\mathrm{mmol} / \mathrm{L}) \\
\text { vs } \\
\text { comparator }\end{array}$ & $\begin{array}{c}\text { Difference } \\
\text { in body } \\
\text { weight }(\mathrm{kg}) \\
\text { vs } \\
\text { comparator }\end{array}$ & $\begin{array}{c}\text { Difference } \\
\text { in SBP } \\
(\mathrm{mmHg}) \\
\text { vs } \\
\text { comparator }\end{array}$ & $\begin{array}{c}\text { Difference } \\
\text { in Total } \\
\text { Cholesterol } \\
\text { (mmol/L) } \\
\text { vs } \\
\text { comparator }\end{array}$ \\
\hline $\begin{array}{c}\text { LEAD } 1 \\
\text { (Marre) } \\
(2009)\end{array}$ & 26 & SU & Placebo & 8.4 & $\begin{array}{c}-1.3 \\
(<0.0001) \\
(\text { Lira } 1.2 \\
\mathrm{mg}) \\
\\
-1.4 \\
(<0.0001) \\
(\text { Lira } 1.8 \\
\mathrm{mg})\end{array}$ & $\begin{array}{c}-2.8 \\
(<0.0001) \\
(\text { Lira } 1.2 \\
\mathrm{mg}) \\
\\
-2.8 \\
(<0.0001) \\
(\text { Lira } 1.8 \\
\mathrm{mg})\end{array}$ & $\begin{array}{l}\text { NS } \\
\text { NS }\end{array}$ & $\begin{array}{l}\text { NS } \\
\text { NS }\end{array}$ & Not stated \\
\hline $\begin{array}{c}\text { LEAD } 1 \\
\text { (Marre) } \\
(2009)\end{array}$ & 26 & SU & TZD & 8.4 & $\begin{array}{c}-0.6 \\
(<0.0001) \\
(\text { Lira } 1.2 \\
\mathrm{mg}) \\
\\
-0.7 \\
(<0.0001) \\
(\text { Lira } 1.8 \\
\mathrm{mg})\end{array}$ & $\begin{array}{c}-0.7 \\
(<0.01) \\
(\text { Lira } 1.2 \\
\mathrm{mg}) \\
\\
-0.7 \\
(<0.01) \\
(\text { Lira } 1.8 \\
\mathrm{mg})\end{array}$ & $\begin{array}{c}-1.4 \\
(<0.0001) \\
(\text { Lira } 1.2 \\
\mathrm{mg}) \\
\\
-2.3 \\
(<0.0001) \\
(\text { Lira } 1.8 \\
\mathrm{mg})\end{array}$ & $\begin{array}{l}\text { NS } \\
\text { NS }\end{array}$ & Not stated \\
\hline $\begin{array}{c}\text { LEAD } 2 \\
\text { (Nauck) } \\
(2009)\end{array}$ & 26 & MF & Placebo & 8.4 & $\begin{array}{c}-1.1 \\
(<0.0001) \\
(\text { Lira } 1.2 \\
\mathrm{mg}) \\
\\
-1.1 \\
(<0.0001) \\
(\text { Lira } 1.8 \\
\mathrm{mg})\end{array}$ & $\begin{array}{c}-2.0 \\
(<0.0001) \\
(\text { Lira } 1.2 \\
\mathrm{mg}) \\
\\
-2.1 \\
(<0.0001) \\
(\text { Lira } 1.8 \\
\mathrm{mg})\end{array}$ & $\begin{array}{c}-1.5 \\
(<0.01) \\
(\text { Lira } 1.2 \\
\text { mg) } \\
\\
-1.5 \\
(<0.01) \\
(\text { Lira } 1.8 \\
\text { mg) }\end{array}$ & Not stated & Not stated \\
\hline $\begin{array}{c}\text { LEAD } 2 \\
\text { (Nauck) } \\
(2009)\end{array}$ & 26 & MF & SU & 8.4 & $\begin{array}{c}\text { NS } \\
\text { (Lira } 1.2 \\
\text { mg) } \\
\\
\text { NS } \\
\text { (Lira } 1.8 \\
\text { mg) }\end{array}$ & $\begin{array}{c}\mathrm{NS} \\
\text { (Lira } 1.2 \\
\mathrm{mg}) \\
\\
\mathrm{NS} \\
\text { (Lira 1.8 } \\
\text { mg) }\end{array}$ & $\begin{array}{c}-3.6 \\
(<0.0001) \\
(\text { Lira 1.2 } \\
\text { mg) } \\
\\
-3.8 \\
(<0.0001) \\
(\text { Lira } 1.8 \\
\text { mg) }\end{array}$ & Not stated & Not stated \\
\hline $\begin{array}{c}\text { LEAD } 3 \\
\text { (Garber) } \\
(\mathbf{2 0 0 9 )}\end{array}$ & 52 & None & SU & 8.2 & $\begin{array}{c}-0.4 \\
(0.04) \\
(\text { Lira } 1.2 \\
\text { mg) } \\
\\
-1.1 \\
(0.002) \\
(\text { Lira } 1.8 \\
\text { mg) }\end{array}$ & $\begin{array}{c}-0.6 \\
(0.02) \\
(\text { Lira } 1.2 \\
\mathrm{mg}) \\
\\
-0.99 \\
(0.0003) \\
\text { (Lira 1.8 } \\
\text { mg) }\end{array}$ & $\begin{array}{c}-2.8 \\
(<0.0001) \\
(\text { Lira } 1.2 \\
\mathrm{mg}) \\
\\
-3.7 \\
(<0.0001) \\
(\text { Lira } 1.8 \\
\text { mg) }\end{array}$ & $\begin{array}{c}-0.86 \\
(0.47) \\
\text { (Lira 1.2 } \\
\text { mg) } \\
\\
-1.9 \\
(0.11) \\
\text { (Lira 1.8 } \\
\text { mg) }\end{array}$ & Not stated \\
\hline
\end{tabular}




\section{Appendix 1 - Supplementary Table S2 continued}

Summary of randomised controlled trials (RCTs) of liraglutide (LEAD studies)

\begin{tabular}{|c|c|c|c|c|c|c|c|c|c|}
\hline $\begin{array}{l}\text { Study } \\
\text { (RCT) }\end{array}$ & $\begin{array}{c}\text { Duration of } \\
\text { the study } \\
\text { (weeks) }\end{array}$ & $\begin{array}{c}\text { Background } \\
\text { therapy }\end{array}$ & Comparator & $\begin{array}{c}\text { Baseline } \\
\text { HbA1C (\%) }\end{array}$ & $\begin{array}{c}\text { Difference } \\
\text { in HbA1c } \\
(\%) \\
\text { vs } \\
\text { comparator }\end{array}$ & $\begin{array}{c}\text { Difference } \\
\text { in FPG } \\
(\mathrm{mmol} / \mathrm{L}) \\
\text { vs } \\
\text { comparator }\end{array}$ & $\begin{array}{c}\text { Difference } \\
\text { in body } \\
\text { weight }(\mathrm{kg}) \\
\text { vs } \\
\text { comparator }\end{array}$ & $\begin{array}{c}\text { Difference } \\
\text { in SBP } \\
(\mathbf{m m H g}) \\
\text { vs } \\
\text { comparator }\end{array}$ & $\begin{array}{c}\text { Difference } \\
\text { in Total } \\
\text { Cholesterol } \\
\text { (mmol/L) } \\
\text { vs } \\
\text { comparator }\end{array}$ \\
\hline $\begin{array}{c}\text { LEAD } 4 \\
\text { (Zinman) } \\
(2009)\end{array}$ & 26 & $\mathrm{MF}+\mathrm{TZD}$ & Placebo & 8.5 & $\begin{array}{c}-1.0 \\
(<0.01) \\
(\text { Lira } 1.2 \\
\mathrm{mg}) \\
\\
-1.3 \\
(<0.01) \\
(\text { Lira } 1.8 \\
\mathrm{mg})\end{array}$ & $\begin{array}{c}-1.8 \\
(<0.001) \\
(\text { Lira } 1.2 \\
\mathrm{mg}) \\
\\
-2.0 \\
(<0.001) \\
(\text { Lira } 1.8 \\
\mathrm{mg})\end{array}$ & $\begin{array}{c}-1.6 \\
(<0.0001) \\
(\text { Lira } 1.2 \\
\text { mg) } \\
\\
-2.6 \\
(<0.0001) \\
(\text { Lira } 1.8 \\
\text { mg) }\end{array}$ & $\begin{array}{c}-5.6 \\
(<0.0001) \\
(\text { Lira } 1.2 \\
\mathrm{mg}) \\
-4.5 \\
(<0.0009) \\
(\text { Lira } 1.8 \\
\text { mg) }\end{array}$ & NS \\
\hline $\begin{array}{l}\text { LEAD } 5 \\
\text { (Russell- } \\
\text { Jones) } \\
(2009)\end{array}$ & 26 & $\mathrm{MF}+\mathrm{SU}$ & Placebo & 8.3 & $\begin{array}{c}-1.1 \\
(<0.0001) \\
(\text { Lira 1.8 } \\
\text { mg) }\end{array}$ & $\begin{array}{c}-2.1 \\
(<0.0001) \\
(\text { Lira 1.8 } \\
\text { mg) }\end{array}$ & $\begin{array}{c}-1.4 \\
(0.0001) \\
(\text { Lira } 1.8 \\
\text { mg) }\end{array}$ & $\begin{array}{c}-2.2 \\
(0.08) \\
(\text { Lira } 1.8 \\
\text { mg) }\end{array}$ & Not stated \\
\hline $\begin{array}{l}\text { LEAD 5 } \\
\text { (Russell- } \\
\text { Jones) } \\
(2009)\end{array}$ & 26 & $\mathrm{MF}+\mathrm{SU}$ & Glargine & 8.3 & $\begin{array}{c}-0.2 \\
(0.002) \\
(\text { Lira } 1.8 \\
\text { mg) }\end{array}$ & NS & $\begin{array}{c}-3.4 \\
(<0.0001) \\
(\text { Lira 1.8 } \\
\text { mg) }\end{array}$ & $\begin{array}{c}-4.5 \\
(0.0001) \\
(\text { Lira } 1.8 \\
\mathrm{mg})\end{array}$ & Not stated \\
\hline $\begin{array}{c}\text { LEAD } 6 \\
\text { (Buse) } \\
(2009)\end{array}$ & 26 & $\mathrm{MF} \pm \mathrm{SU}$ & EBID & 8.2 & $\begin{array}{c}-0.3 \\
(<0.0001) \\
(\text { Lira 1.8 } \\
\text { mg) }\end{array}$ & $\begin{array}{c}-1.0 \\
(<0.0001) \\
(\text { Lira 1.8 } \\
\text { mg) }\end{array}$ & $\begin{array}{c}-0.4 \\
(0.22) \\
(\text { Lira } 1.8 \\
\text { mg) }\end{array}$ & $\begin{array}{c}-0.5 \\
(0.064) \\
(\text { Lira 1.8 } \\
\text { mg) }\end{array}$ & $\begin{array}{c}-0.11 \\
(0.09) \\
(\text { Lira } 1.8 \\
\mathrm{mg})\end{array}$ \\
\hline $\begin{array}{c}\text { Pratley } \\
\text { (not LEAD } \\
\text { study) } \\
(2010)\end{array}$ & 26 & MF & Sitagliptin & 8.5 & $\begin{array}{c}-0.3 \\
(<0.0001) \\
(\text { Lira } 1.2 \\
\mathrm{mg}) \\
\\
-0.5 \\
(<0.0001) \\
(\text { Lira } 1.8 \\
\mathrm{mg})\end{array}$ & $\begin{array}{c}-1.9 \\
(<0.0001) \\
(\text { Lira } 1.2 \\
\text { mg) } \\
\\
-2.1 \\
(<0.0001) \\
(\text { Lira } 1.8 \\
\text { mg) }\end{array}$ & $\begin{array}{c}0.4 \\
(0.75) \\
(\text { Lira } 1.2 \\
\text { mg) } \\
\\
0.2 \\
(0.85) \\
(\text { Lira } 1.8 \\
\text { mg) }\end{array}$ & $\begin{array}{c}-0.3 \\
(<0.0001) \\
(\text { Lira } 1.2 \\
\mathrm{mg}) \\
\\
-0.5 \\
(<0.0001) \\
(\text { Lira } 1.8 \\
\mathrm{mg})\end{array}$ & $\begin{array}{c}-0.01 \\
(0.85) \\
(\text { Lira } 1.2 \\
\text { mg) } \\
-0.16 \\
(0.03) \\
(\text { Lira } 1.8 \\
\text { mg) }\end{array}$ \\
\hline
\end{tabular}




\section{Appendix 1 - Supplementary Table S3}

Summary of randomised controlled trials (RCTs) of lixisenatide (GetGoal Studies)

\begin{tabular}{|c|c|c|c|c|c|c|c|c|c|}
\hline $\begin{array}{l}\text { Study } \\
\text { (RCT) }\end{array}$ & $\begin{array}{l}\text { Duration of } \\
\text { the study } \\
\text { (weeks) }\end{array}$ & $\begin{array}{c}\text { Background } \\
\text { therapy }\end{array}$ & Comparator & $\begin{array}{c}\text { Baseline } \\
\text { HbA1C }(\%)\end{array}$ & $\begin{array}{c}\text { Difference } \\
\text { in HbA1c } \\
(\%) \\
\text { vs } \\
\text { comparator }\end{array}$ & $\begin{array}{c}\text { Difference } \\
\text { in FPG } \\
(\mathrm{mmol} / \mathrm{L}) \\
\text { vs } \\
\text { comparator }\end{array}$ & $\begin{array}{c}\text { Difference } \\
\text { in body } \\
\text { weight }(\mathrm{kg}) \\
\text { vs } \\
\text { comparator }\end{array}$ & $\begin{array}{c}\text { Difference } \\
\text { in SBP } \\
(\mathrm{mmHg}) \\
\text { vs } \\
\text { comparator }\end{array}$ & $\begin{array}{c}\text { Difference } \\
\text { in Total } \\
\text { Cholesterol } \\
\text { (mmol/L) } \\
\text { vs } \\
\text { comparator }\end{array}$ \\
\hline $\begin{array}{c}\text { GetGoal- } \\
\text { mono } \\
\text { (Fonseca) } \\
\text { (2012) }\end{array}$ & 12 & None & Placebo & 8.0 & $\begin{array}{c}-0.7 \\
(<0.0001)\end{array}$ & $\begin{array}{c}-1.1 \\
(<0.0001)\end{array}$ & NS & Not stated & Not stated \\
\hline $\begin{array}{c}\text { GetGoal- } \\
\text { Duo } 1 \\
\text { (Riddle) } \\
\text { (2013) }\end{array}$ & 24 & $\begin{array}{c}\text { Glargine }+ \\
\mathrm{MF} \pm \mathrm{TZD}\end{array}$ & Placebo & 9.1 & $\begin{array}{c}-0.3 \\
(<0.0001)\end{array}$ & NS & $\begin{array}{c}-0.9 \\
(0.001)\end{array}$ & Not stated & Not stated \\
\hline $\begin{array}{c}\text { GetGoal- } \\
\text { Duo-F1 } \\
\text { (Bolli) } \\
\text { (2013) }\end{array}$ & 24 & MF & Placebo & 8.0 & $\begin{array}{c}-0.5 \\
(<0.0001)\end{array}$ & $\begin{array}{c}-0.7 \\
(<0.001)\end{array}$ & $\begin{array}{c}-1.0 \\
(<0.01)\end{array}$ & Not stated & Not stated \\
\hline $\begin{array}{c}\text { GetGoal-X } \\
\text { (Rosenstock } \\
\text { ) } \\
(2013)\end{array}$ & 24 & $\mathrm{MF}$ & EBID & 8.0 & $\begin{array}{c}\text { NS } \\
\text { (Not } \\
\text { inferior to } \\
\text { EBID) }\end{array}$ & $\begin{array}{c}\text { NS } \\
\text { (Not } \\
\text { inferior to } \\
\text { EBID) }\end{array}$ & $\begin{array}{c}1.0 \\
(0.05) \\
\text { (Greater } \\
\text { weight loss } \\
\text { with EBID) }\end{array}$ & Not stated & Not stated \\
\hline $\begin{array}{c}\text { GetGoal-S } \\
\text { (Rosenstock } \\
\text { ) } \\
(2014)\end{array}$ & 24 & $\mathrm{SU} \pm \mathrm{MF}$ & Placebo & 8.5 & $\begin{array}{c}-1.1 \\
(<0.0001)\end{array}$ & $\begin{array}{c}-0.7 \\
(0.05)\end{array}$ & $\begin{array}{c}-0.1 \\
(0.76)\end{array}$ & Not stated & Not stated \\
\hline $\begin{array}{c}\text { GetGoal-P } \\
\text { (Pinget) } \\
(2013)\end{array}$ & 24 & $\mathrm{TZD} \pm \mathrm{MF}$ & Placebo & 8.1 & $\begin{array}{c}-0.6 \\
(<0.0001)\end{array}$ & $\begin{array}{c}-0.8 \\
(<0.0001)\end{array}$ & NS & Not stated & Not stated \\
\hline $\begin{array}{c}\text { GetGoal-M } \\
\text { (Ahren) } \\
(2013)\end{array}$ & 24 & MF & Placebo & 8.1 & $\begin{array}{c}-0.5 \\
(0.0001)\end{array}$ & $\begin{array}{c}-0.9 \\
(0.005)\end{array}$ & NS & Not stated & Not stated \\
\hline $\begin{array}{c}\text { GetGoal-M } \\
\text { Asia } \\
\text { (Yu Pan) } \\
(2014)\end{array}$ & 24 & $\mathrm{MF} \pm \mathrm{SU}$ & Placebo & 7.9 & $\begin{array}{c}-0.4 \\
(0.0004)\end{array}$ & $\begin{array}{c}-0.5 \\
(0.01)\end{array}$ & NS & Not stated & Not stated \\
\hline $\begin{array}{l}\text { GetGoal-L } \\
\text { (Riddle) } \\
(\mathbf{2 0 1 3})\end{array}$ & 24 & $\begin{array}{c}\text { Basal insulin } \\
\pm \mathrm{MF}\end{array}$ & Placebo & 8.4 & $\begin{array}{c}-0.4 \\
(0.0002)\end{array}$ & NS & $\begin{array}{c}-1.3 \\
(0.0001)\end{array}$ & Not stated & Not stated \\
\hline
\end{tabular}


Appendix 1 - Supplementary Table S3 continued

Summary of randomised controlled trials (RCTs) of lixisenatide (GetGoal Studies)

\begin{tabular}{|c|c|c|c|c|c|c|c|c|c|}
\hline $\begin{array}{l}\text { Study } \\
\text { (RCT) }\end{array}$ & $\begin{array}{l}\text { Duration of } \\
\text { the study } \\
\text { (weeks) }\end{array}$ & $\begin{array}{c}\text { Background } \\
\text { therapy }\end{array}$ & Comparator & $\begin{array}{c}\text { Baseline } \\
\text { HbA1C }(\%)\end{array}$ & $\begin{array}{c}\text { Difference } \\
\text { in HbA1c } \\
(\%) \\
\text { vs } \\
\text { comparator }\end{array}$ & $\begin{array}{c}\text { Difference } \\
\text { in FPG } \\
(\mathrm{mmol} / \mathrm{L}) \\
\text { vs } \\
\text { comparator }\end{array}$ & $\begin{array}{c}\text { Difference } \\
\text { in body } \\
\text { weight (kg) } \\
\text { vs } \\
\text { comparator }\end{array}$ & $\begin{array}{c}\text { Difference } \\
\text { in SBP } \\
(\mathrm{mmHg}) \\
\text { vs } \\
\text { comparator }\end{array}$ & $\begin{array}{c}\text { Difference } \\
\text { in Total } \\
\text { Cholesterol } \\
\text { (mmol/L) } \\
\text { vs } \\
\text { comparator }\end{array}$ \\
\hline $\begin{array}{c}\text { GetGoal-L } \\
\text { Asia } \\
\text { (Seino) } \\
\text { (2012) }\end{array}$ & 24 & $\begin{array}{c}\text { Basal insulin } \\
\pm \mathrm{SU}\end{array}$ & Placebo & 8.5 & $\begin{array}{c}-0.9 \\
(<0.0001)\end{array}$ & Not stated & NS & Not stated & Not stated \\
\hline $\begin{array}{c}\text { GetGoal-L } \\
\text { Asia } \\
\text { (Seino) } \\
\text { (2012) }\end{array}$ & 24 & MF & & & & & & & \\
\hline
\end{tabular}




\section{Appendix 1 - Supplementary Table S4}

\section{Summary of randomized controlled trials (RCTs) of once-weekly exenatide (EQW) (DURATION studies)}

\begin{tabular}{|c|c|c|c|c|c|c|c|c|c|}
\hline $\begin{array}{l}\text { Study } \\
\text { (RCT) }\end{array}$ & $\begin{array}{l}\text { Duration of } \\
\text { the study } \\
\text { (weeks) }\end{array}$ & $\begin{array}{l}\text { Background } \\
\text { therapy }\end{array}$ & Comparator & $\begin{array}{c}\text { Baseline } \\
\text { HbA1C (\%) }\end{array}$ & $\begin{array}{c}\text { Difference } \\
\text { in HbA1c } \\
(\%) \\
\text { vs } \\
\text { comparator }\end{array}$ & $\begin{array}{c}\text { Difference } \\
\text { in FPG } \\
(\mathrm{mmol} / \mathrm{L}) \\
\text { vs } \\
\text { comparator }\end{array}$ & $\begin{array}{c}\text { Difference } \\
\text { in body } \\
\text { weight (kg) } \\
\text { vs } \\
\text { comparator }\end{array}$ & $\begin{array}{c}\text { Difference } \\
\text { in SBP } \\
(\mathrm{mmHg}) \\
\text { vs } \\
\text { comparator }\end{array}$ & $\begin{array}{c}\text { Difference } \\
\text { in Total } \\
\text { Cholesterol } \\
(\mathrm{mmol} / \mathrm{L}) \\
\text { vs } \\
\text { comparator }\end{array}$ \\
\hline $\begin{array}{c}\text { DURATIO } \\
\text { N 1 } \\
\text { (Drucker) } \\
\text { (2008) }\end{array}$ & 30 & $\begin{array}{c}\mathrm{MF} \pm \\
\mathrm{SU} \pm \mathrm{TZD}\end{array}$ & $\begin{array}{l}\text { Placebo } \\
\text { EBID }\end{array}$ & 8.3 & $\begin{array}{c}\text { Not stated } \\
\\
-0.5 \\
(0.002)\end{array}$ & $\begin{array}{c}\text { Not stated } \\
\\
-0.9 \\
(<0.0001)\end{array}$ & $\begin{array}{c}\text { Not stated } \\
\text { NS }\end{array}$ & $\begin{array}{c}\text { Not stated } \\
\text { NS }\end{array}$ & $\begin{array}{c}\text { Not stated } \\
\text { NS }\end{array}$ \\
\hline $\begin{array}{c}\text { DURATIO } \\
\text { N } 2 \\
\text { (Bergenstal) } \\
\text { (2010) }\end{array}$ & 26 & $\mathrm{MF}$ & Sitagliptin & 8.5 & $\begin{array}{c}-0.6 \\
(<0.001)\end{array}$ & $\begin{array}{c}-0.9 \\
(0.004)\end{array}$ & $\begin{array}{c}-2.3 \\
(<0.0001)\end{array}$ & $\begin{array}{c}-4.0 \\
(0.006)\end{array}$ & Not stated \\
\hline $\begin{array}{c}\text { DURATIO } \\
\text { N } 2 \\
\text { (Bergenstal) } \\
\text { (2010) }\end{array}$ & 26 & $\mathrm{MF}$ & TZD & 8.5 & $\begin{array}{c}-0.3 \\
(0.02)\end{array}$ & NS & $\begin{array}{c}-5.1 \\
(<0.0001)\end{array}$ & NS & Not stated \\
\hline $\begin{array}{c}\text { DURATIO } \\
\text { N } 3 \\
\text { (Diamant) } \\
\text { (2010) }\end{array}$ & 26 & $\mathrm{MF} \pm \mathrm{SU}$ & Glargine & 8.3 & $\begin{array}{c}-0.2 \\
(0.03)\end{array}$ & $\begin{array}{c}0.6 \\
(0.001)\end{array}$ & $\begin{array}{c}-4.0 \\
(<0.0001)\end{array}$ & $\begin{array}{c}-2.0 \\
(0.0001)\end{array}$ & NS \\
\hline $\begin{array}{c}\text { DURATIO } \\
\text { N } 4 \\
\text { (Russell- } \\
\text { Jones) } \\
\text { (2012) }\end{array}$ & 26 & Placebo & MF & 8.5 & NS & Not stated & $\begin{array}{c}\text { No } \\
\text { significant } \\
\text { difference }\end{array}$ & Not stated & Not stated \\
\hline $\begin{array}{c}\text { DURATIO } \\
\text { N } 4 \\
\text { (Russell- } \\
\text { Jones) } \\
\text { (2012) }\end{array}$ & 26 & Placebo & TZD & 8.5 & $\begin{array}{c}0.1 \\
(0.32)\end{array}$ & Not stated & $\begin{array}{c}-3.5 \\
(<0.001)\end{array}$ & Not stated & Not stated \\
\hline $\begin{array}{c}\text { DURATIO } \\
\text { N } 4 \\
\text { (Russell- } \\
\text { Jones) } \\
\text { (2012) }\end{array}$ & 26 & Placebo & Sitagliptin & 8.5 & $\begin{array}{c}-0.3 \\
(<0.001)\end{array}$ & Not stated & $\begin{array}{c}-1.2 \\
(<0.001)\end{array}$ & Not stated & Not stated \\
\hline $\begin{array}{c}\text { DURATIO } \\
\text { N } 5 \\
\text { (Belvins) } \\
\text { (2011) }\end{array}$ & 24 & $\begin{array}{c}\mathrm{MF} \pm \\
\mathrm{SU} \pm \mathrm{TZD}\end{array}$ & EBID & 8.4 & $\begin{array}{c}-0.7 \\
(<0.0001)\end{array}$ & $\begin{array}{c}-1.2 \\
(0.0008)\end{array}$ & NS & NS & $\begin{array}{l}-0.52 \\
(<0.01)\end{array}$ \\
\hline $\begin{array}{c}\text { DURATIO } \\
\text { N } 6 \\
\text { (Buse) } \\
\text { (2013) }\end{array}$ & 26 & $\mathrm{MF} \pm \mathrm{SU}$ & $\begin{array}{c}\text { Lira (1.8 } \\
\mathrm{mg})\end{array}$ & 8.5 & $\begin{array}{c}-0.2 \\
(0.02)\end{array}$ & NS & $\begin{array}{c}-0.9 \\
(0.02)\end{array}$ & NS & NS \\
\hline
\end{tabular}




\section{Appendix 1 - Supplementary Table S5}

Summary of randomised controlled trials (RCTs) of albiglutide (HARMONY studies)

\begin{tabular}{|c|c|c|c|c|c|c|c|c|c|}
\hline $\begin{array}{l}\text { Study } \\
\text { (RCT) }\end{array}$ & $\begin{array}{l}\text { Duration of } \\
\text { the study } \\
\text { (weeks) }\end{array}$ & $\begin{array}{l}\text { Background } \\
\text { therapy }\end{array}$ & Comparator & $\begin{array}{c}\text { Baseline } \\
\text { HbA1C (\%) }\end{array}$ & $\begin{array}{c}\text { Difference } \\
\text { in HbA1c } \\
(\%) \\
\text { vs } \\
\text { comparator }\end{array}$ & $\begin{array}{c}\text { Difference } \\
\text { in FPG } \\
(\mathrm{mmol} / \mathrm{L}) \\
\text { vs } \\
\text { comparator }\end{array}$ & $\begin{array}{c}\text { Difference } \\
\text { in body } \\
\text { weight }(\mathrm{kg}) \\
\text { vs } \\
\text { comparator }\end{array}$ & $\begin{array}{c}\text { Difference } \\
\text { in } \mathrm{SBP} \\
(\mathrm{mmHg}) \\
\text { vs } \\
\text { comparator }\end{array}$ & $\begin{array}{c}\text { Difference } \\
\text { in Total } \\
\text { Cholesterol } \\
(\mathrm{mmol} / \mathrm{L}) \\
\text { vs } \\
\text { comparator }\end{array}$ \\
\hline $\begin{array}{c}\text { HARMON } \\
\text { Y } 1 \\
\text { (Reusch) } \\
\text { (2013) }\end{array}$ & 52 & $\mathrm{TZD} \pm \mathrm{MF}$ & Placebo & 8.1 & $\begin{array}{c}-0.8 \\
(<0.0001)\end{array}$ & $\begin{array}{c}-1.6 \\
(<0.0001)\end{array}$ & NS & Not stated & Not stated \\
\hline $\begin{array}{c}\text { HARMON } \\
\text { Y 2 } \\
\text { (Reinhardt) } \\
(2013)\end{array}$ & 52 & None & Placebo & 8.1 & $\begin{array}{c}-1.0 \\
(<0.001)\end{array}$ & & NS & & \\
\hline $\begin{array}{c}\text { HARMON } \\
\text { Y 3 } \\
\text { (Ahren) } \\
\text { (2014) }\end{array}$ & 104 & $\overline{M F}$ & $\begin{array}{c}\text { Placebo } \\
\text { Sitagliptin } \\
\text { SU }\end{array}$ & 8.1 & $\begin{array}{c}-0.9 \\
(<0.0001) \\
\\
-0.4 \\
(<0.0001) \\
\\
-0.3 \\
(0.003)\end{array}$ & $\begin{array}{c}-1.5 \\
(<0.0001) \\
\\
-0.9 \\
(0.0002) \\
\\
-0.6 \\
(0.013)\end{array}$ & $\begin{array}{c}\text { NS } \\
\text { NS } \\
\\
-2.4 \\
(<0.0001)\end{array}$ & $\begin{array}{l}\text { Not stated } \\
\text { Not stated } \\
\text { Not stated }\end{array}$ & $\begin{array}{l}\text { Not stated } \\
\text { Not stated } \\
\text { Not stated }\end{array}$ \\
\hline $\begin{array}{c}\text { HARMON } \\
\text { Y 4 } \\
\text { (Weissman) } \\
\text { (2014) }\end{array}$ & 52 & $\mathrm{MF} \pm \mathrm{SU}$ & Glargine & 8.3 & $\begin{array}{c}-0.1 \\
(0.15)\end{array}$ & $\begin{array}{c}1.2 \\
(<0.0001)\end{array}$ & $\begin{array}{c}-2.6 \\
(<0.0001)\end{array}$ & Not stated & Not stated \\
\hline $\begin{array}{c}\text { HARMON } \\
\text { Y 5 } \\
\text { (Home) } \\
(2015)\end{array}$ & 52 & $\mathrm{MF}+\mathrm{SU}$ & $\begin{array}{c}\text { Placebo } \\
\text { TZD }\end{array}$ & 8.2 & $\begin{array}{c}-0.9 \\
(<0.0001) \\
\\
0.3 \\
(0.08)\end{array}$ & $\begin{array}{c}0.6 \\
(<0.001) \\
\\
1.1 \\
(<0.001)\end{array}$ & $\begin{array}{c}\text { NS } \\
\\
\\
-4.9 \\
(<0.0001)\end{array}$ & Not stated & Not stated \\
\hline $\begin{array}{c}\text { HARMON } \\
\text { Y } 6 \\
\text { (Rosenstock } \\
\text { ) } \\
(2014)\end{array}$ & 26 & $\begin{array}{c}\text { Basal insulin } \\
\pm \mathrm{TZD} \pm \mathrm{MF}\end{array}$ & Insulin lispro & 8.5 & NS & NS & $\begin{array}{c}-1.5 \\
(<0.0001)\end{array}$ & Not stated & Not stated \\
\hline $\begin{array}{c}\text { HARMON } \\
\text { Y } 7 \\
\text { (Pratley) } \\
\text { (2014) }\end{array}$ & 32 & $\begin{array}{c}\mathrm{MF} \pm \\
\mathrm{SU} \pm \mathrm{TZD}\end{array}$ & $\begin{array}{c}\text { Lira (1.8 } \\
\mathrm{mg})\end{array}$ & 8.1 & NS & $\begin{array}{c}0.5 \\
(0.0048)\end{array}$ & $\begin{array}{c}-1.5 \\
(<0.0001)\end{array}$ & Not stated & Not stated \\
\hline
\end{tabular}




\section{Appendix 1 - Supplementary Table S6}

Summary of randomised controlled trials (RCTs) of dulaglutide (AWARD studies)

\begin{tabular}{|c|c|c|c|c|c|c|c|c|c|}
\hline $\begin{array}{l}\text { Study } \\
\text { (RCT) }\end{array}$ & $\begin{array}{l}\text { Duration of } \\
\text { the study } \\
\text { (weeks) }\end{array}$ & $\begin{array}{c}\text { Background } \\
\text { therapy }\end{array}$ & Comparator & $\begin{array}{c}\text { Baseline } \\
\text { HbA1C (\%) }\end{array}$ & $\begin{array}{c}\text { Difference } \\
\text { in HbA1c } \\
(\%) \\
\text { vs } \\
\text { comparator }\end{array}$ & $\begin{array}{c}\text { Difference } \\
\text { in FPG } \\
(\mathrm{mmol} / \mathrm{L}) \\
\text { vs } \\
\text { comparator }\end{array}$ & $\begin{array}{c}\text { Difference } \\
\text { in body } \\
\text { weight }(\mathrm{kg}) \\
\text { vs } \\
\text { comparator }\end{array}$ & $\begin{array}{c}\text { Difference } \\
\text { in } \\
\text { SBP } \\
(\mathrm{mmHg}) \\
\text { vs } \\
\text { comparator }\end{array}$ & $\begin{array}{c}\text { Difference } \\
\text { in Total } \\
\text { Cholesterol } \\
(\mathrm{mmol} / \mathrm{L}) \\
\text { vs } \\
\text { comparator }\end{array}$ \\
\hline $\begin{array}{c}\text { AWARD } 1 \\
\text { (Wysham) } \\
(2014)\end{array}$ & 52 & $\mathrm{MF}+\mathrm{TZD}$ & $\begin{array}{l}\text { Placebo } \\
\text { EBID }\end{array}$ & 8.1 & $\begin{array}{c}-1.0 \\
(<0.001) \\
\\
-0.52 \\
(<0.001)\end{array}$ & $\begin{array}{c}\text { Not stated } \\
\begin{array}{c}-1.0 \\
(<0.001)\end{array}\end{array}$ & $\begin{array}{c}-2.5 \\
(<0.0001) \\
\text { NS }\end{array}$ & $\begin{array}{c}\text { Not stated } \\
\text { NS }\end{array}$ & $\begin{array}{l}\text { Not stated } \\
\text { Not stated }\end{array}$ \\
\hline $\begin{array}{c}\text { AWARD } 2 \\
\text { (Giorgino) } \\
(2015)\end{array}$ & 52 & $\mathrm{MF}+\mathrm{SU}$ & Glargine & 8.1 & $\begin{array}{c}-0.6 \\
(<0.001)\end{array}$ & NS & $\begin{array}{c}-3.31 \\
(<0.001)\end{array}$ & Not stated & Not stated \\
\hline $\begin{array}{c}\text { AWARD } 3 \\
\text { (Umpierrez) } \\
(\mathbf{2 0 1 4 )}\end{array}$ & 52 & None & MF & 7.6 & $\begin{array}{l}-0.20 \\
(0.02)\end{array}$ & $\begin{array}{c}-0.4 \\
(0.025)\end{array}$ & NS & NS & Not stated \\
\hline $\begin{array}{c}\text { AWARD } 4 \\
\text { (Blonde) } \\
(2015)\end{array}$ & 52 & $\begin{array}{l}\text { Basal } \pm \\
\text { prandial } \\
\text { insulin }\end{array}$ & $\begin{array}{l}\text { Placebo } \\
\text { Glargine }\end{array}$ & 8.5 & $\begin{array}{c}-1.2 \\
(<0.001) \\
\\
-0.22 \\
(0.005)\end{array}$ & $\begin{array}{c}\text { Not stated } \\
\\
1.31 \\
(<0.0001)\end{array}$ & $\begin{array}{c}\text { Not stated } \\
\\
-3.2 \\
(<0.0001)\end{array}$ & $\begin{array}{c}\text { Not stated } \\
\text { NS }\end{array}$ & $\begin{array}{c}\text { Not stated } \\
\text { NS }\end{array}$ \\
\hline $\begin{array}{c}\text { AWARD } 5 \\
\text { (Nauck) } \\
(2014)\end{array}$ & 52 & MF & Sitagliptin & 8.1 & $\begin{array}{c}-0.7 \\
(<0.001)\end{array}$ & Significant & $\begin{array}{c}-1.5 \\
(<0.001)\end{array}$ & NS & NS \\
\hline $\begin{array}{c}\text { AWARD } 6 \\
\text { (Dungan) } \\
\text { (2014) }\end{array}$ & 26 & MF & $\begin{array}{c}\text { Lira (1.8 } \\
\text { mg) }\end{array}$ & 8.1 & $\begin{array}{c}-0.1 \\
(<0.0001)\end{array}$ & NS & $\begin{array}{c}0.7 \\
(0.01)\end{array}$ & NS & Not stated \\
\hline
\end{tabular}

